\title{
Constituents from Maytenus Ilicifolia Leaves and Bioguided Fractionation for Gastroprotective Activity
}

\author{
João Paulo V. Leite, ${ }^{*}, a$ Fernão C. Braga ${ }^{b}$ Giovanni Romussi, ${ }^{c}$ Rita M. Persoli, ${ }^{d}$ \\ Ricardo Tabach, ${ }^{d}$ Elisaldo A. Carlini ${ }^{d}$ and Alaíde B. Oliveira ${ }^{b}$
}

${ }^{a}$ Departamento de Bioquímica e Biologia Molecular, Universidade Federal de Viçosa, Av. Peter Henry Rolfs s/n, 36570-000 Viçosa-MG, Brazil

${ }^{b}$ Departamento de Produtos Farmacêuticos, Faculdade de Farmácia, Universidade Federal de Minas Gerais, Av. Antônio Carlos, 6627, 31270-901 Belo Horizonte-MG, Brazil

${ }^{c}$ Dipartamento di Chimica e Tecnologie Farmaceutiche, Università degli Studi di Genova, Via Brigata Salerno, 16147 Genoa, Italy

${ }^{d}$ Departamento de Psicobiologia, Universidade Federal de São Paulo, R. Napoleão de Barros, 925, 04024-003 São Paulo-SP, Brazil

\begin{abstract}
Maytenus ilicifolia Mart. ex Reissek é tradicionalmente usada no Brasil para o tratamento de úlcera gástrica. O presente trabalho relata a investigação fitoquímica de um extrato etanólico de folhas de M. ilicifolia (EEMIL) visando o isolamento de constituintes que foram usados como marcadores químicos para monitorar o fracionamento de um extrato aquoso liofilizado de folhas de M. ilicifolia (LAEMIL). De EEMIL, quatro flavonóides foram isolados, compreendendo o triglicosídeo flavônico mauritianina (1), trifolina (2), hyperina (4), e epi-catequina (5). O fracionamento de LAEMIL levou a 5 frações, fornecendo um derivado tetraglicosilado de canferol (3), além do galactitol (6). LAEMIL e suas frações foram avaliadas quanto aos efeitos sobre o volume e $\mathrm{pH}$ da secreção gástrica em ratos. Análise por CLAE (Cromatografia Líquida de Alta Eficiência) revelou que somente frações contendo o tri- e tetra-glicosídeos flavônicos $\mathbf{1}$ e $\mathbf{3}$ causaram aumento significativo de volume gástrico e pH, indicando que esses glicosídeos têm importante papel sob o efeito gastroprotetor de folhas de $M$. ilicifolia.
\end{abstract}

Maytenus ilicifolia Mart. ex Reissek is traditionally used in Brazil for treatment of gastric ulcers. Here we report the phytochemical investigation of an ethanol extract of M. ilicifolia leaves (EEMIL) aiming at the isolation of constituents which were used as chemical markers to monitor an activity-guided fractionation of a lyophilized aqueous extract of M. ilicifolia leaves (LAEMIL). From EEMIL, four flavonoids were isolated, namely the tri-flavonoid glycosides mauritianin (1), trifolin, (2) hyperin (4), and epi-catechin (5). Fractionation of LAEMIL led to 5 fractions which afforded the tetra-glycoside kaempferol derivative (3), and galactitol (6). LAEMIL and its fractions were evaluated in rats for their effects on gastric secretion volume and $\mathrm{pH}$. HPLC (High Performance Liquid Chromatography) analysis revealed that only fractions containing the tri- and tetra-flavonoid glycosides $\mathbf{1}$ and $\mathbf{3}$ caused significant increase of gastric volume and $\mathrm{pH}$, thus indicating that these glycosides play an important role on the gastroprotective effect of M.ilicifolia leaves.

Keywords: Maytenus ilicifolia, flavonoid glycosides, gastroprotective activity, liquid chromatography

\section{Introduction}

Maytenus ilicifolia Mart. ex. Reissek belongs to the Celastraceae, a pantropical family. The species is

*e-mail: jpvleite@ufv.br popularly known as "espinheira-santa", being found in Southern Brazil, and its leaves are traditionally used to treat dispepsy and gastric ulcers. ${ }^{1}$ The antiulcerogenic activity of $M$. ilicifolia leaves is well documented. Its aqueous extract causes significant reduction in the number of gastric ulcers induced by both indomethacin and cold- 
restraint stress in rats. This protection was similar to that observed with cimetidine, a well known histamine $\mathrm{H}_{2}$ receptor antagonist. ${ }^{2-4}$ Investigation of the possible mechanism of action of LAEMIL showed that, as in the case of cimetidine, it antagonises histamine $\mathrm{H}_{2}$ receptors, although other mechanisms cannot be ruled out. ${ }^{5} M$. ilicifolia leaves showed neither toxic nor teratologic effects when a lyophilized aqueous extract was administered for long periods of time (up to 3 months) and at high doses to rats and mice. ${ }^{6}$ The chemical constituents obtained from these plant extracts with solvents of different polarities are: terpenoids, flavonoids, tannins and polysaccharides. ${ }^{7-11}$ We have previously reported the phytochemical study of an infusion of $M$. ilicifolia leaves when three known flavonoid glycosides and a novel flavonoid tetra-glycoside were isolated. ${ }^{8}$ We have also reported the anti-inflammatory and antiulcerogenic activities of $n$-hexane and ethyl acetate extracts from $M$. ilicifolia leaves and have postulated a correlation between these pharmacological effects and flavonoids. ${ }^{12}$ Recently, Baggio and collaborators reported the potent in vivo gastroprotective properties of a flavonoidrich fraction separated from the leaves of M. ilicifolia, containing galactitol (25\%), epicatechin (3.1\%) and catechin (2\%) as major constituents, which was correlated with the in vitro inhibition of rabbit gastric $\mathrm{H}^{+}, \mathrm{K}^{+}$-ATPase activity. ${ }^{13}$ Aiming to further the investigation on the bioactive constituents from $M$. ilicifolia leaves we have carried out a phytochemical investigation of an ethanol extract of $M$. ilicifolia leaves (EEMIL) for the isolation of compounds which were further used as chemical markers to monitor an activity-guided fractionation of a lyophilized aqueous extract of $M$. ilicifolia leaves (LAEMIL). Finally, HPLC analyses of LAEMIL and its chromatographic fractions were carried out, aiming at establishing a correlation between gastroprotective effect and chemical composition.

\section{Experimental}

\section{General experimental procedures}

${ }^{1} \mathrm{H}$ and ${ }^{13} \mathrm{C}$ NMR spectra were registered in a Bruker DRX-600 and in a Bruker Advance DRX-400 apparatus. Mass spectra were registered in a FINNIGAN MAT90 spectrometer operating with ionization energy of $159 \mathrm{eV}$, at positive and negative modes. IR and UV-Vis spectra were registered in the spectrophotometers Shimadzu IR-408, in $\mathrm{KBr}$ discs, and Shimadzu UV-160A, respectively. Melting points were determined in a MQAPF-301 apparatus (Microquímica, Brazil). Column chromatography (CC) was undertaken over Macherey Naneg SC6 poliamide, silica gel Merck 60 (0.063-0.200 mm) and Sephadex LH-20 (Pharmacia). A DCC Cromatograph Buchi 670 apparatus was employed for countercurrent chromatography. Silica gel chromatofoils $60 \mathrm{~F}_{254}$ (Merck) were used for TLC analyses.

\section{Plant material}

Leaves of $M$. ilicifolia were collected from native populations, at the municipality of Lapa, State of Paraná, Brazil, by the agricultural engineer Paulo Guilherme Ribeiro, Instituto Agronômico do Paraná - IAPAR, on June 1999. A voucher specimen was deposited at the Herbarium of the Universidade Federal de Londrina, Londrina, State of Paraná, Brazil (code number FUEL 21881). After drying at room temperature for 5 days, the leaves were ground in a knife mill.

\section{Isolation of compounds 1, 2, 4 and 5 from EEMIL}

EEMIL (191.0 g) was obtained by percolation of the dried powder from $M$. ilicifolia leaves $(959 \mathrm{~g})$ after previous sequential extraction with $n$-hexane and ethyl acetate. A portion of EEMIL ( $24 \mathrm{~g}$ ) was submitted to chromatography over Sephadex LH-20 columns $(12 \times 2 \mathrm{~g}$, each column $)$ eluted with methanol; fractions were combined into 6 groups according to their TLC analysis. Group 2 (fractions $7-11 ; 4.4 \mathrm{~g})$ was chromatographed on a poliamide column eluted with water followed by water:methanol solutions with increasing contents of methanol (20-70\%) and finishing with methanol. The collected fractions (298, $25 \mathrm{~mL}$ each) were combined according to their TLC analysis. Fractions 14-191 (1.3 g; eluted with water:methanol, 4:1) were dissolved in methanol (25 mL), filtered and injected onto a DCC apparatus. The lower layer of a mixture of chloroform:methanol:water, (8:10:5), thoroughly equilibrated in a separation funnel by repeated vigorous shaking, was used as stationary phase. The upper layer of this mixture was used as mobile phase and it was pumped into the column at a flow-rate of $0.5 \mathrm{~mL} / \mathrm{min}$ affording 234 fractions ( $25 \mathrm{~mL}$ each). The DCC fractions were appropriately combined and after recrystallization (methanol:acetone, 1:1) afforded compound 1 (380 mg). Group 4 (fractions 15-21; $4.7 \mathrm{~g}$ ) from the initial Sephadex LH-20 column, after successive injections of aliquots $(4 \times 1.0 \mathrm{~g})$ onto the DCC apparatus employing the same system as described here, and combination of these fractions according to TLC profiles, afforded 7 groups. Re-chromatograhy on Sephadex LH-20 columns and/or recrystallizations of fractions 2,3 and 4 afforded compounds 2 (20 mg, recrystallization from methanol), 
4 (12 mg, recrystallization in methanol) and 5 (540 mg, recrystallization from water).

\section{Preparation of LAEMIL}

LAEMIL was prepared according to the traditional use, as described by Carlini. ${ }^{2}$ Boiling water was added to dried leaves powder $(400 \mathrm{~g})$ of $M$. ilicifolia, in the proportion of $3 \mathrm{~g}$ leaves: $100 \mathrm{~mL}$ water and the flask was kept covered for $15 \mathrm{~min}$. The aqueous extract was separated by filtration in a Buchner funnel and was lyophilized, yielding $78 \mathrm{~g}(19.5 \%)$.

\section{Bioactivity-guided fractionation of LAEMIL and isolation of compounds 1, 3 and 6}

LAEMIL (40 g) was dissolved in $100 \mathrm{~mL}$ of water and was chromatographed on a poliamide column $(600 \times 35 \mathrm{~mm}$ i.d.). For elution, a gradient of water and methanol was used, affording 5 fractions which were concentrated in a rotary evaporator (F1 water $100 \%, 35.0 \mathrm{~g}$; F2 water:methanol, 7:3, $2.21 \mathrm{~g}$; F3 water:methanol, 1:1, $1.55 \mathrm{~g}$; F4 water:methanol, 3:7, $0.91 \mathrm{~g} ;$ F5 methanol 100\%, $1.06 \mathrm{~g}$ ). During the concentration in a rotary evaporator, F1 afforded 6, as a white crystalline compound ( $30 \mathrm{~g})$. F2 and F3, after successive fractionations on Sephadex LH-20 and silica gel columns, followed by recrystallizations, led to $\mathbf{1}$ (110 mg, recrystallization in methanol:acetone, 1:1) and 3 (500 mg, recrystallization from methanol:acetone, 1:1). LAEMIL and the fractions obtained from the poliamide column were evaluated in rats for the gastric secretion volume and $\mathrm{pH}$. F1 - F5 were characterized by TLC and HPLC fingerprints, employing the isolated compounds 1-5 as chemical markers.

\section{HPLC analysis of LAEMIL and fractions F1 - F 5}

Analyses were carried out on a Merck-Hitachi apparatus (Germany) composed of pump L6200-A, automatic injector AS-2000A, UV-Vis detector L-4250 and integrator D-2500. An ODS column ( $150 \times 4.0 \mathrm{~mm}$, i.d. $5 \mu \mathrm{m})$ was employed (Merck Darmstadt, Germany), at a temperature of $40^{\circ} \mathrm{C}$ and flow rate of $1.0 \mathrm{~mL} / \mathrm{min}$. UV-Vis detection was set at $254 \mathrm{~nm}$. A linear gradient of water (A) and methanol (B) was employed (0-35 min, 0-90\% B) followed by 10 min of isocratic elution. Solvents used were of HPLC grade (Merck Darmstadt, Germany) and were degassed by sonication before use. Samples were dissolved in methanol to concentrations of $3.0 \mathrm{mg} / \mathrm{mL}$ (LAEMIL) and $1 \mathrm{mg} / \mathrm{mL}$ (F1-F5 and compounds 1-5), under sonication, for $15 \mathrm{~min}$. After centrifugation at 10,000 r.p.m., the sample solutions
$(20 \mu \mathrm{L})$ were automatically injected onto the HPLC apparatus.

\section{Animals}

Male Wistar rats (3-4 months age) weighing 300-350 g were provided by Animal House of the Departamento de Psicobiologia, Universidade Federal de São Paulo (UNIFESP) and were kept in polypropylene cages $(32 \times$ $40 \times 18 \mathrm{~cm}, 4$ animals per cage) in rooms with $12 \mathrm{~h}$ light/ dark cycle (lights on at 6:00 a.m.), at controlled temperature $\left(23 \pm 2{ }^{\circ} \mathrm{C}\right)$. Food and water were available ad libitum. The Committee of Ethics in Research of UNIFESP approved the experimental protocol (CEP 297/00).

\section{Determination of gastric secretion volume and $p H$}

To groups of 7 or 8 rats, which were fasted overnight before experiments, were administered (i.p.) water (control group), LAEMIL (140 mg/kg) and fractions (F1 - F5) from poliamide column (14 mg/kg each). After $1 \mathrm{~h}$, the animals were sacrificed in a $\mathrm{CO}_{2}$ chamber; their stomachs were ligated $2 \mathrm{~cm}$ below the pylorus and a small incision was made near the pylorus to collect the gastric juice. The volume was measured and $\mathrm{pH}$ determinations were done by using $\mathrm{pH}$ indicator paper strips (Spezialind. Kator, pH 2.5-4.5 and 4.0-7.0, Merck, Darmstadt).

\section{Statistical analyses}

One-way ANOVA method, followed by multiple comparisons was used to analyze the results. The statistical significance considered was $p<0.05$ (confidence limit: $95 \%)$.

\section{Isolated compounds}

Compound 1 (mauritianin). Colourless amorphous powder, mp 196-198 ${ }^{\circ} \mathrm{C}$ (from methanol:acetone, 1:1) (lit. 202-204 ${ }^{\circ} \mathrm{C}$ ). The complete spectrometric data were described in reference. ${ }^{8}$

Compound 2 (trifolin). Yellow crystals, $\mathrm{mp} 242-245^{\circ} \mathrm{C}$ (from methanol) (lit. 254-256 ${ }^{\circ} \mathrm{C}$ )..$^{14}$

Compound 3. Yellowish amorphous powder, mp 269-271 ${ }^{\circ} \mathrm{C}$ (from methanol:acetone, 1:1). The complete spectrometric data were described in reference. ${ }^{8}$

Compound 4 (hyperin). Yellow crystals, mp $232-234^{\circ} \mathrm{C}$ (lit. 238-239 $\left.{ }^{\circ} \mathrm{C}\right) .{ }^{15}$

Compound 5 (epi-catechin). Colourless amorphous powder, mp $208-211^{\circ} \mathrm{C}$, comercial sample SIGMA. (lit. 206-210 $\left.{ }^{\circ} \mathrm{C}\right){ }^{16}$ 
Compound 6 (galactitol). Colourless crystals, mp 188-190 ${ }^{\circ} \mathrm{C}$ (lit. $\left.187.5-188.5^{\circ} \mathrm{C}\right) .{ }^{17}$

\section{Results and Discussion}

EEMIL was initially submitted to chromatography on a Sephadex LH-20 column and the fractions obtained were rechromatographed on poliamide columns and on a DCC apparatus to yield compounds 1, 2, 4 and 5 (Figure 1). We have previously isolated one of these compounds from an infusion of $M$. ilicifolia leaves, the known tri-glycoside kaempferol-3- $O$ - $\alpha$-L-rhamnopyranosyl $(1 \rightarrow 6)-O$ - $[\alpha$ L-rhamnopyranosyl $(1 \rightarrow 2)]-O-\beta$-D-galactopyranoside (mauritianin) (1), along with another tri-glycoside, quercetin-3- $O$ - $\alpha$-L-rhamnopyranosyl $(1 \rightarrow 6)-O$ - $[\alpha-\mathrm{L}$ rhamnopyranosyl $(1 \rightarrow 2)]-O-\beta$-D-galactopyranoside

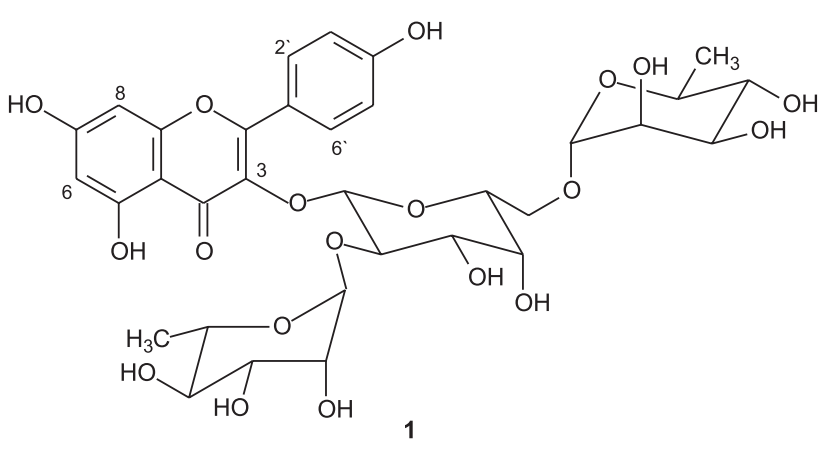

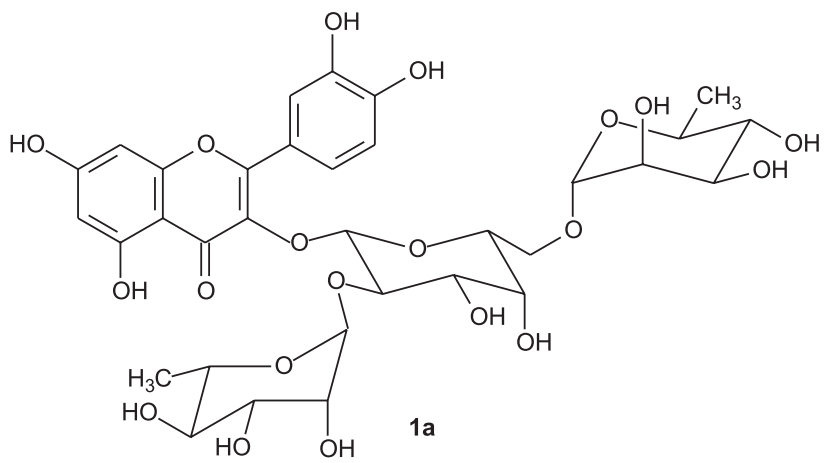

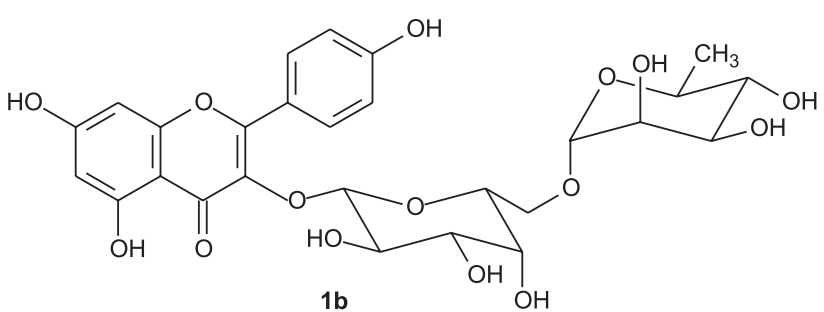<smiles>O=c1c(OC2OC3C(O)C(O)C(O)C(O)C3O2)c(-c2ccc(O)cc2)oc2cc(O)cc(O)c12</smiles>

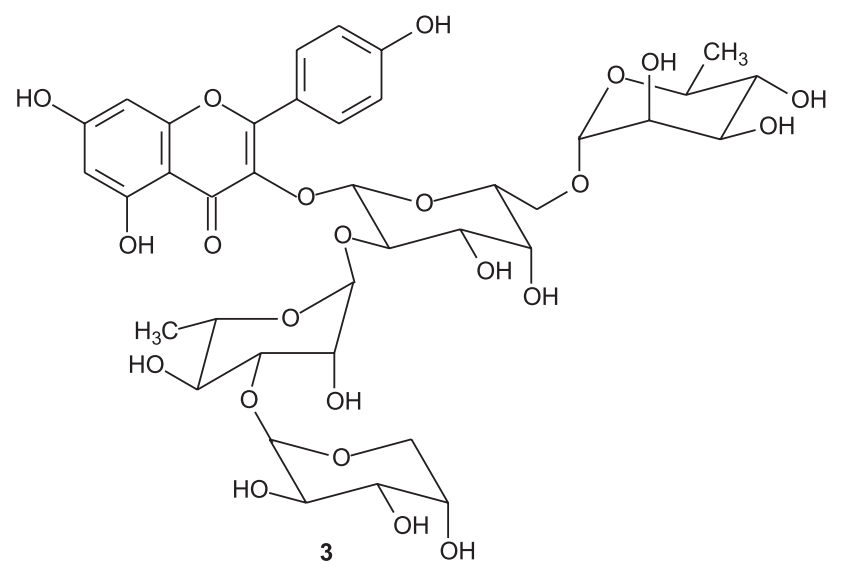<smiles>O=c1c(OC2OC(CO)C(O)C(O)C(O)C2O)c(-c2ccc(O)c(O)c2)oc2cc(O)cc(O)c12</smiles><smiles>Oc1cc(O)c2c(c1)O[C@H](c1ccc(O)c(O)c1)[C@H](O)C2</smiles><smiles>OCC(O)C(O)C(O)C(O)C(O)C(O)O</smiles>

6

Figure 1. Chemical structures of compounds isolated from M. ilicifolia leaves. For the isolation of $\mathbf{1 a}$ and $\mathbf{1 b}$, see Leite et al. $^{8}$ (2001). 
(1a) and the di-glycoside kaempferol- 3- $O$ - $\alpha$-Lrhamnopyranosyl $(1 \rightarrow 2)$ - $O$ - $\beta$-D-galactopyranoside $(\mathbf{1 b}){ }^{8}$ It seems that the presence of the mono-glycoside trifolin (kaempferol-3-O- $\beta$-D-galactopyranoside) (2) in $M$. ilicifolia leaves is being reported here by the first time while hyperin (quercetin-3-O- $\beta$-D-galactopyranoside) (4) and epi-catechin (5) were recently described for this species..$^{10,13}$ Isolated compounds were identified by direct comparison with authentic samples $(\mathbf{1})^{8}$ and with data registered in the literature $(\mathbf{2}, \mathbf{4}$ and $\mathbf{5})$. $^{14-16}$

LAEMIL was prepared according to the traditional use of the species, as described by Carlini, ${ }^{2}$ and was submitted to chromatography on a poliamide column eluted with a gradient of water and methanol, affording 5 fractions (F1 - F5). On concentration of $\mathrm{F} 1$, the poliol galactitol (dulcitol) (6) crystallized out, being identified as the major constituent and representing about $75 \%$ of LAEMIL. F2 and F3, after successive fractionations on Sephadex LH-20 and silica gel columns, besides recrystallization, afforded the previously known tri-glycoside 1 along with the tetra-glycoside kaempferol-3-O- $\alpha$-L-rhamnopyranosyl $(1 \rightarrow 6)-O$ - $[\beta$-D- arabinopyranosyl $(1 \rightarrow 3)$ - $O$ - $\alpha$-L-rhamnopyranosyl $(1 \rightarrow 2)$ ]$O$ - $\beta$-D-galactopyranoside (3) which, when firstly isolated from M. ilicifolia leaves, represented a novel compound and was fully characterized, chemically and spectrometrically. ${ }^{8}$

LAEMIL and the fractions from the poliamide column (F1 - F5) were analyzed by TLC and RP-HPLC, employing compounds 1-5 as chemical markers. Flavonoid glycosides $\mathbf{1}$ and $\mathbf{3}$ showed close retention times (RT $=21.75$ and $21.66 \mathrm{~min}$ ) when injected separately, while for $\mathbf{2 , 4}$ and 5 very distinct peaks were observed $(\mathrm{RT}=24.22,22.75$ and $14.92 \mathrm{~min}$, respectively). A mixture of compounds 1-5, analyzed in the same conditions, displayed only 4 peaks with superposition of the signals of $\mathbf{1}$ and $\mathbf{3}$ $(\mathrm{RT}=21.96 \mathrm{~min})$. The HPLC fingerprint obtained for LAEMIL revealed an intense peak at $21.78 \mathrm{~min}$, corresponding to the coelution of $\mathbf{1}$ and $\mathbf{3}$, besides peaks at $24.50,22.86$ and $15.07 \mathrm{~min}$, which were attributed to compounds $\mathbf{2}, \mathbf{4}$ and $\mathbf{5}$, respectively. HPLC chromatography profiles registered for F1 - F5 (Figure 2), followed by coinjection of each fraction with compounds 1-5, showed that F1 contains none of the chemical markers, a result further
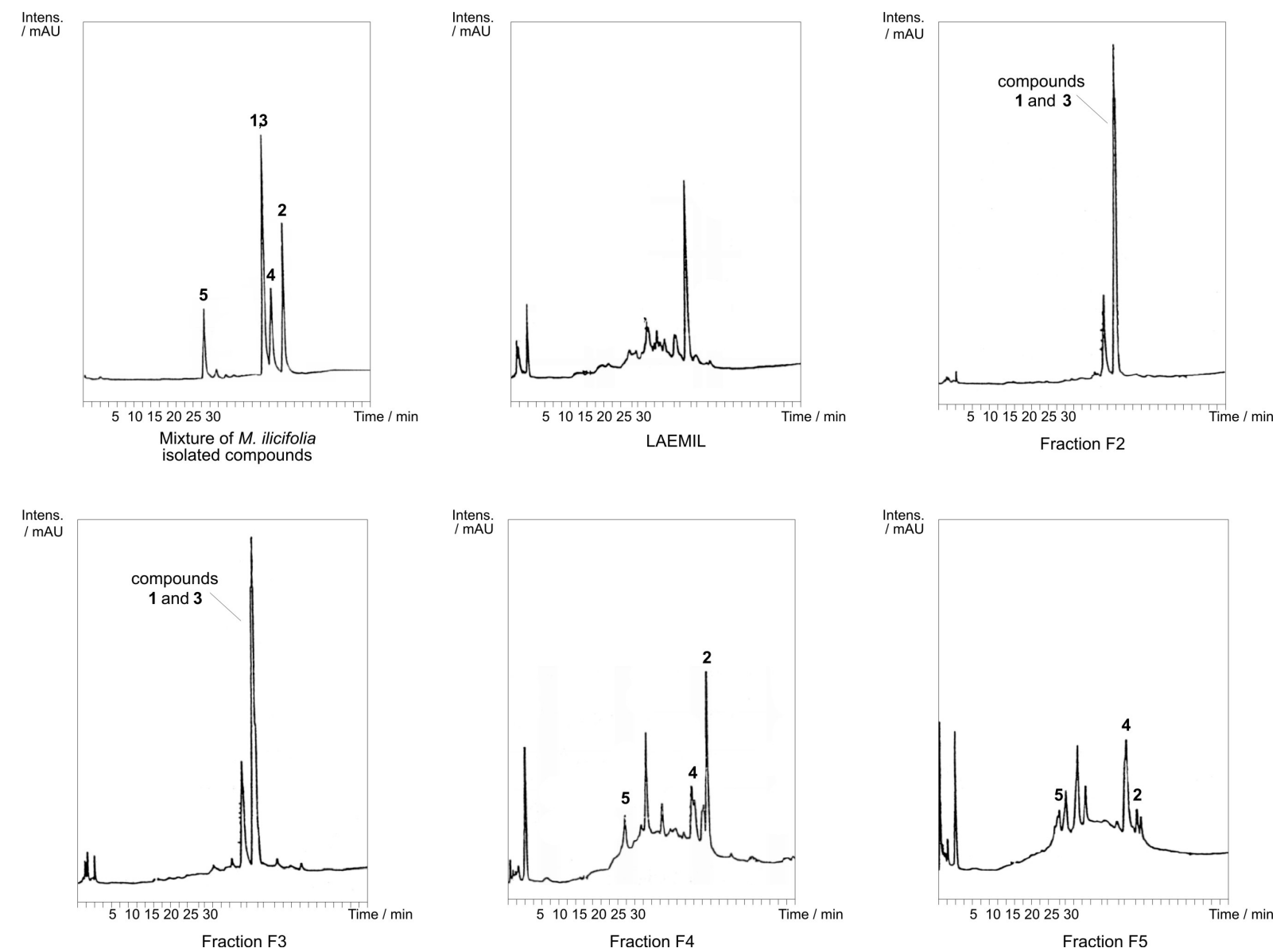

Figure 2. HPLC chromatographic profile obtained for compounds 1-5 and fractions F2, F3, F4 and F5 from M. ilicifolia leaves. HPLC conditions: column ODS Lichrospher, $250 \times 4.6 \mathrm{~mm}$ i.d., $5 \mu \mathrm{m}$ particle size; mobile phases: a linear gradient of water, A / methanol, B (0-35 min, 0-90\% B); flow rate: $1.0 \mathrm{~mL} / \mathrm{min}$; detection: UV-Vis, $254 \mathrm{~nm}$. 
Table 1. Effect on gastric secretion volume (mL) and $\mathrm{pH}$ of rats pretreated (i.p.) with LAEMIL and F1 - F5

\begin{tabular}{lcc}
\hline Sample & Dosis $(\mathrm{mg} / \mathrm{kg})$ & Gastric volume $(\mathrm{mL})$ \\
\hline Control (water) & ---- & $0.28 \pm 0.09$ \\
LAEMIL & 140 & $0.34 \pm 0.18^{\mathrm{a}}$ \\
F1 (water) & 14 & $0.23 \pm 0.16$ \\
F2 (water:methanol, 7:3) & 14 & $0.39 \pm 0.17^{\mathrm{a}}$ \\
F3 (water:methanol, 1:1) & 14 & $0.40 \pm 0.17^{\mathrm{a}}$ \\
F4 (water:methanol, 3:7) & 14 & $0.26 \pm 0.10$ \\
F5 (methanol) & 14 & $0.38 \pm 0.27^{\mathrm{a}}$ \\
The values represent mean \pm S.E.M. & & $3.03 \pm 0.44^{\mathrm{a}}$ \\
\hline
\end{tabular}

${ }^{a}$ Statistically different from control group $(p<0.05)$.

confirmed by the absence of flavonoid spots on TLC plates. On the other hand, F2 and F3 showed intense peaks with RT at 21.72 and $21.75 \mathrm{~min}$, corresponding to the kaempferol glycosides $\mathbf{1}$ and $\mathbf{3}$. Trifolin (2), hyperin (4) and epi-catechin (5) showed more intense peaks in F4 (RT 24.47, 22.70 and 14.90 min, respectively) than in F5 (RT $=24.55,22.83$ and $14.96 \mathrm{~min})$. Proanthocyanidins were detected by TLC (spray reagent: $1 \%$ vanillin-methanol solution; eluent: $8 \%$ hydrochloric acid-methanol) in fractions F4 and F5, but were not isolated in the present investigation although previously reported in M. ilicifolia. ${ }^{18}$

LAEMIL and the fractions derived from it (F1 - F5) were evaluated in rats for their effects on gastric secretion volume and $\mathrm{pH}$ (Table 1). A significant increase in gastric secretion volume and $\mathrm{pH}$ was observed for LAEMIL and these data were higher for F2 and F3 though they had been assayed in doses ten times smaller to that of LAEMIL. F1 and F4 did not differ significantly from the control group. In its turn, F5 increased the gastric secretion volume but no significant effect was observed on the $\mathrm{pH}$. The biological profile observed for LAEMIL, F2 and F3 on the gastric secretion volume and $\mathrm{pH}$ is similar to that originally obtained by our research group for a lyophilized aqueous extract ("abafado") ( $170 \mathrm{mg} / \mathrm{kg}$ ), which was shown to be comparable to those of cimetidine $(50 \mathrm{mg} / \mathrm{kg}$ ), a standard antiulcerogenic drug used as positive control. ${ }^{2-3}$ LAEMIL was prepared according to Carlini's recipe ${ }^{2}$ and the evaluation of the gastric secretion volume and $\mathrm{pH}$ was carried out at his own laboratory confirming its possible gastroproptective and antiulcerogenic effects.

\section{Conclusions}

The flavonoid tri- and tetra-glycosides $\mathbf{1}$ and $\mathbf{3}$ obtained from a poliamide column of LAEMIL, and that are present in the active fractions $\mathrm{F} 2$ and $\mathrm{F} 3$, may be the main phenolic constituents responsible for the gastroprotective effect of $M$. ilicifolia leaves. These two phenolics can be considered as the chemical and pharmacological markers for an aqueous extract of M. ilicifolia leaves and their signals clearly stand out in its HPLC chromatography profile. Compounds $\mathbf{2 , 4}$ 5 and proanthocyanidins (condensed tannins) would make a less important contribution to LAEMIL gastroprotective effect since they have been shown to be predominant in F4 and F5 which have not disclosed significant activity on gastric volume and $\mathrm{pH}$ of rats. Finally, a contribution of galactitol for the gastroprotective/antiulcerogenic effect of this plant species should not be underestimated once it is the major constituent of LAEMIL (75\%) and therefore could influence the absorption of the active compounds, since it is used in the production of slow release microcapsules of antiulcer drugs.

\section{Acknowledgments}

The authors thank Dr. Paulo Guilherme Ferreira Ribeiro, Instituto Agronômico do Paraná, Londrina, Brazil, for providing the plant material. This research was financially supported by CNPq (Conselho Nacional de Desenvolvimento Científico e Tecnológico, Brazil) and EU-Alfa Program/RELAPLAMED PROJECT.

\section{Supplementary Information}

MS, ${ }^{1} \mathrm{H}$ NMR, ${ }^{13} \mathrm{C}$ NMR,${ }^{1} \mathrm{H}-{ }^{1} \mathrm{H}$ COSY, HSQC, HMBC, HSQC, TOCSY NMR spectra of compounds 1, 2, 3, 4, 5 and $\mathbf{6}$ are available free of charge at http://jbcs.sbq.org.br, as PDF file.

\section{References}

1. Cruz, G.L.; Dicionário das plantas úteis do Brasil, $2^{\mathrm{a}}$ ed., Civilização Brasileira: São Paulo, Brasil, 1982.

2. Carlini, E.A.; Estudo da ação antiúlcera gástrica de plantas brasileiras: Maytenus ilicifolia (espinheira-santa) e outras. CEME/AFIP: Brasília, Brasil, 1988. 
3. Souza-Formigoni, M. L. O.; Oliveira, M. G.M.; Monteiro, M. G.; Silveira-Filho, N. G.; Braz, S.; Carlini, E. A.; J. Ethnopharmacol. 1991, 34, 21.

4. Tabach, R.; Oliveira, W. P.; Pharmazie 2003, 58, 573.

5. Ferreira, P. M.; de Oliveira, C. N.; de Oliveira, A. B.; Lopes, M. J.; Alzamora, F.; Vieira, M. A.; Planta 2004, 219, 319.

6. Oliveira, M. G. M.; Monteiro, M. G.; Macaúbas, C.; Barbosa, V. P.; Carlini, E. A.; J. Ethnopharmacol. 1991, 34, 29.

7. Queiroga, C. L.; Silva, G. F.; Dias, P. C.; Possenti, A.; Carvalho, J. E.; J. Ethnopharmacol. 2000, 72, 465.

8. Leite, J. P. V.; Rastrelli, L.; Romussi, G.; Oliveira, A. B.; Vilegas, J. H. Y.; Vilegas, W.; Pizza, C.; J. Agric. Food Chem. 2001, 49 , 3796.

9. Cipriani, T. R.; Mellinger, C. G.; Souza, L. M.; Baggio, C. H.; Freitas, C. S.; Marques, M. C.; Gorin, P. A. J.; Sassaki, G. L.; Iacomini, M.; J. Nat. Prod. 2006, 69, 1018.

10. Tiberti, L. A.; Yariwake, J. H.; Ndjoko, K.; Hostettmann, K.; J. Chromatogr., B: Anal. Technol. Biomed. Life Sci. 2007, 846, 378.

11. Gutiérrez, F.; Estévez-Braun, A.; Ravelo, A. G.; Astudilo, L.; Zarate, R.; J. Nat. Prod. 2007, 70, 1049.
12. Jorge, R. M.; Leite, J. P. V.; Oliveira, A. B.; Tagliati, C. A.; J. Ethnopharmacol. 2004, 94, 93.

13. Baggio, C. H.; Freitas, C. S.; Otofuji, G. M.; Cipriani, T. R.; Souza, L. M.; Sassaki, G. L.; Iacomini, M.; Marques, M. C. A.; Mesia-Vela, S.; J. Ethnopharmacol. 2007, 113, 433.

14. Arciniegas, A.; Pérez-Castorena, A. L.; Villaseñor, J. L.; Vivar, A. R.; Biochem. Syst. Ecol. 2004, 32, 615.

15. Yasukawa, K.; Takido, M.; Phytochemistry 1987, 26, 1224.

16. Foo, L. Y.; Newman, R.; Waghorn, G.; Mcnabb, W. C.; Ulyatt, M. J.; Phytochemistry 1996, 41, 617.

17. Wells, W. W.; Pittman, T. A.; Egan, T. J.; J. Biol. Chem. 1965, 240, 1002.

18. De Souza, L. M.; Cipriani, T. R; Iacomini, M.; Gorin, P. A. J.; Sassaki, G. L.; J. Pharm. Biomed. Anal. 2008, 47, 59.

Received: April 1, 2009

Web Release Date: November 12, 2009

FAPESP helped in meeting the publication costs of this article. 


\section{Constituents from Maytenus Ilicifolia Leaves and Bioguided Fractionation for Gastroprotective Activity}

\section{João Paulo V. Leite, ${ }^{*}, a$ Fernão C. Braga ${ }^{b}$ Giovanni Romussi, ${ }^{c}$ Rita M. Persoli, ${ }^{d}$ Ricardo Tabach, ${ }^{d}$ Elisaldo A. Carlini ${ }^{d}$ and Alaíde B. Oliveira ${ }^{b}$}

${ }^{a}$ Departamento de Bioquímica e Biologia Molecular, Universidade Federal de Viçosa,

Av. Peter Henry Rolfs s/n, 36570-000 Viçosa-MG, Brazil

${ }^{b}$ Departamento de Produtos Farmacêuticos, Faculdade de Farmácia, Universidade Federal de Minas Gerais, Av. Antônio Carlos, 6627, 31270-901 Belo Horizonte-MG, Brazil

${ }^{c}$ Dipartamento di Chimica e Tecnologie Farmaceutiche, Università degli Studi di Genova, Via Brigata Salerno, 16147 Genoa, Italy

${ }^{d}$ Departamento de Psicobiologia, Universidade Federal de São Paulo, R. Napoleão de Barros, 925, 04024-003 São Paulo-SP, Brazil

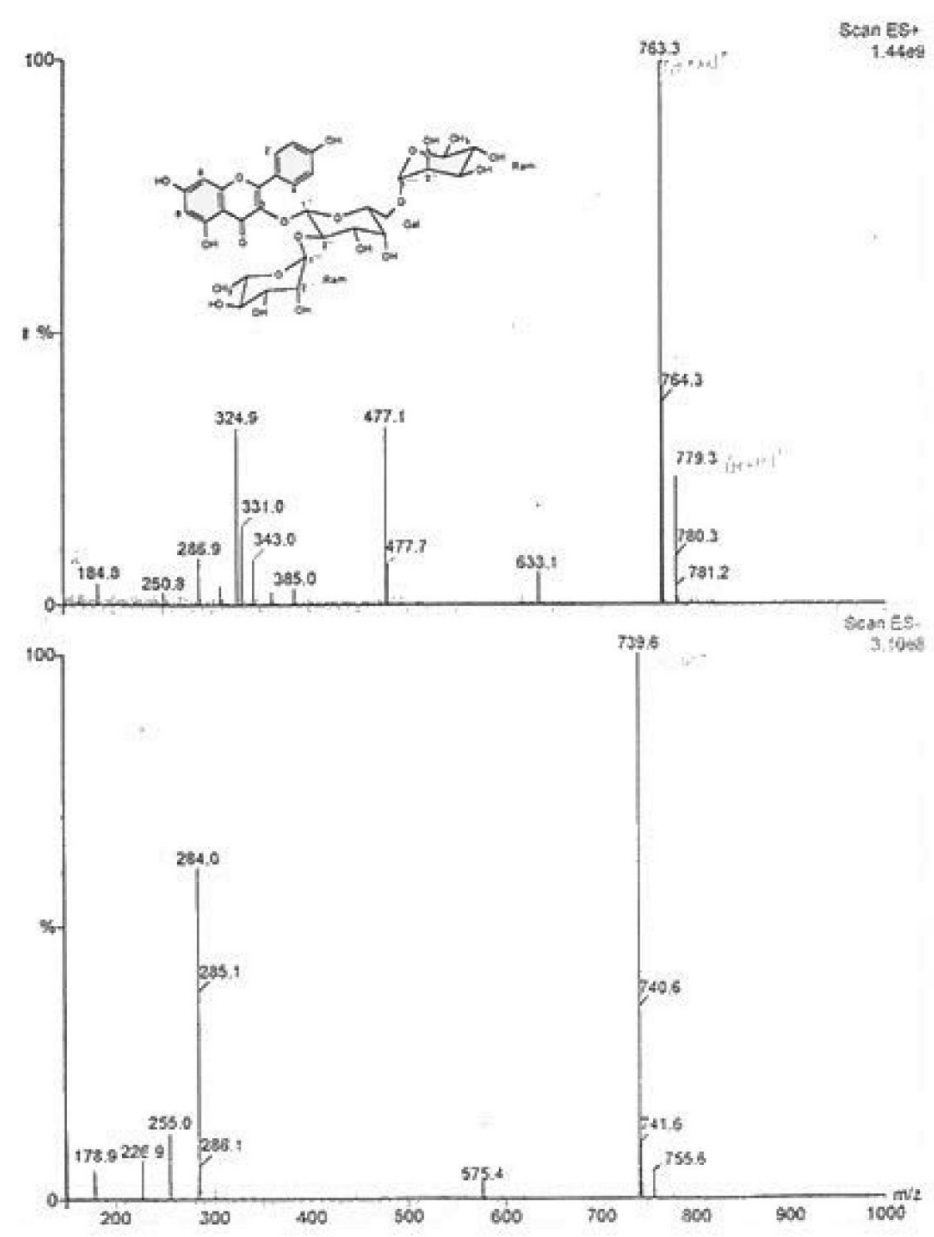

Figure S1. Mass spectrum of compound 1. 


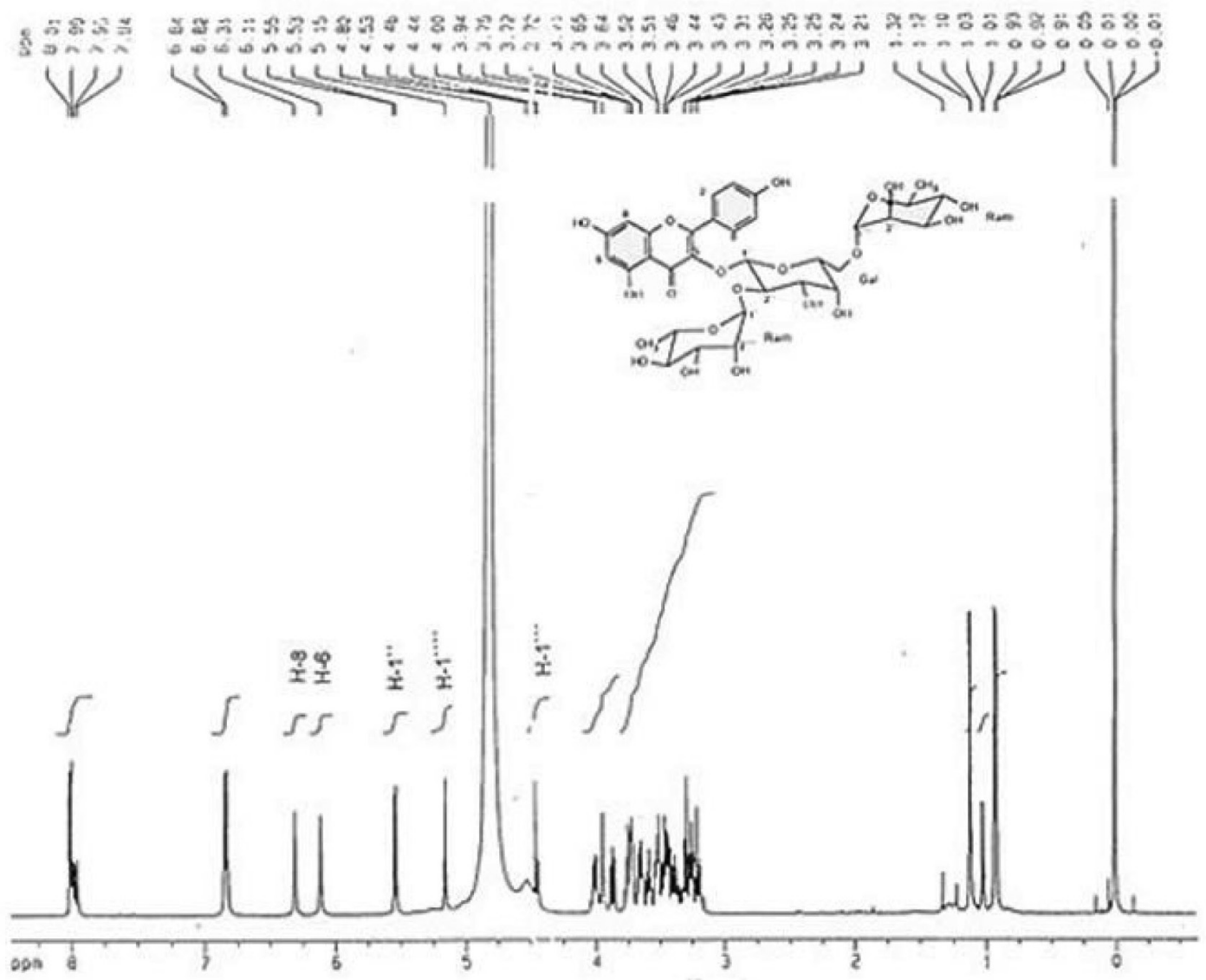

FigureS2. ${ }^{1} \mathrm{H}$ NMR spectrum of compound 1.

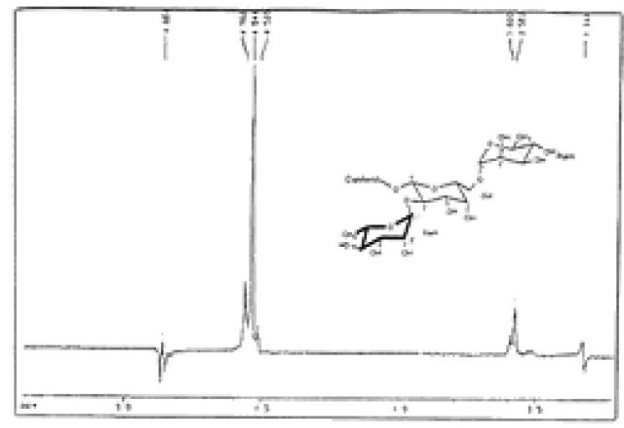

(a)

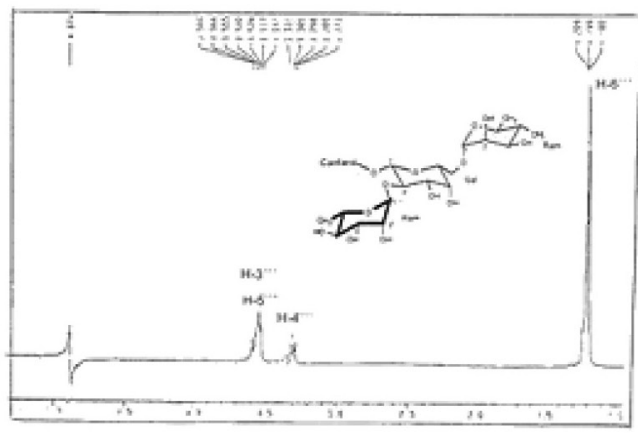

(b)

Figure S3. 'D TOCSY experiment of compound 1; with selective excitation at: a) $\delta 4.54 \mathrm{ppm}$ and b) $\delta 1.19 \mathrm{ppm}$. 


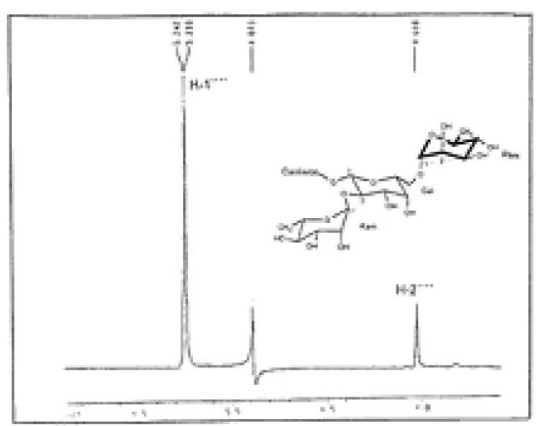

(a)

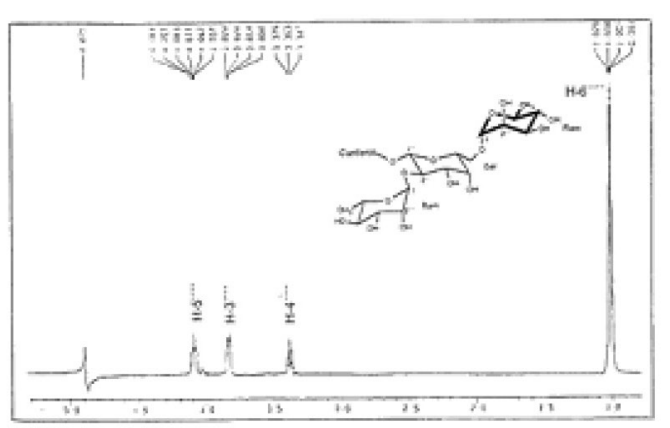

(b)

Figure S4. 'D TOCSY experiment of compound 1 with selective excitation at (a) $\delta 5.24 \mathrm{ppm}$ and (b) $\delta 1.0 \mathrm{ppm}$.

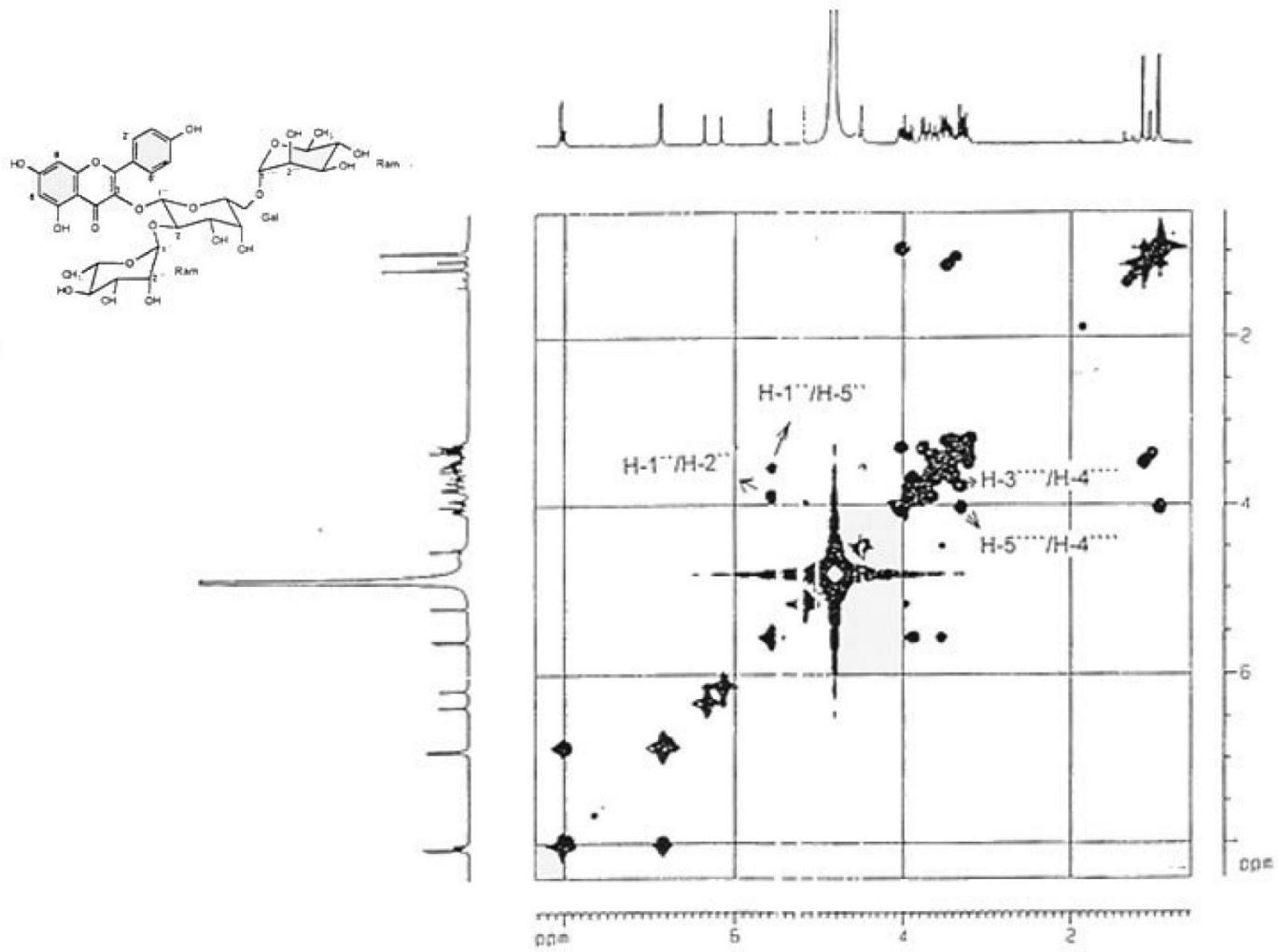

Figure S5. COSY experiment of compound $\mathbf{1}$. 


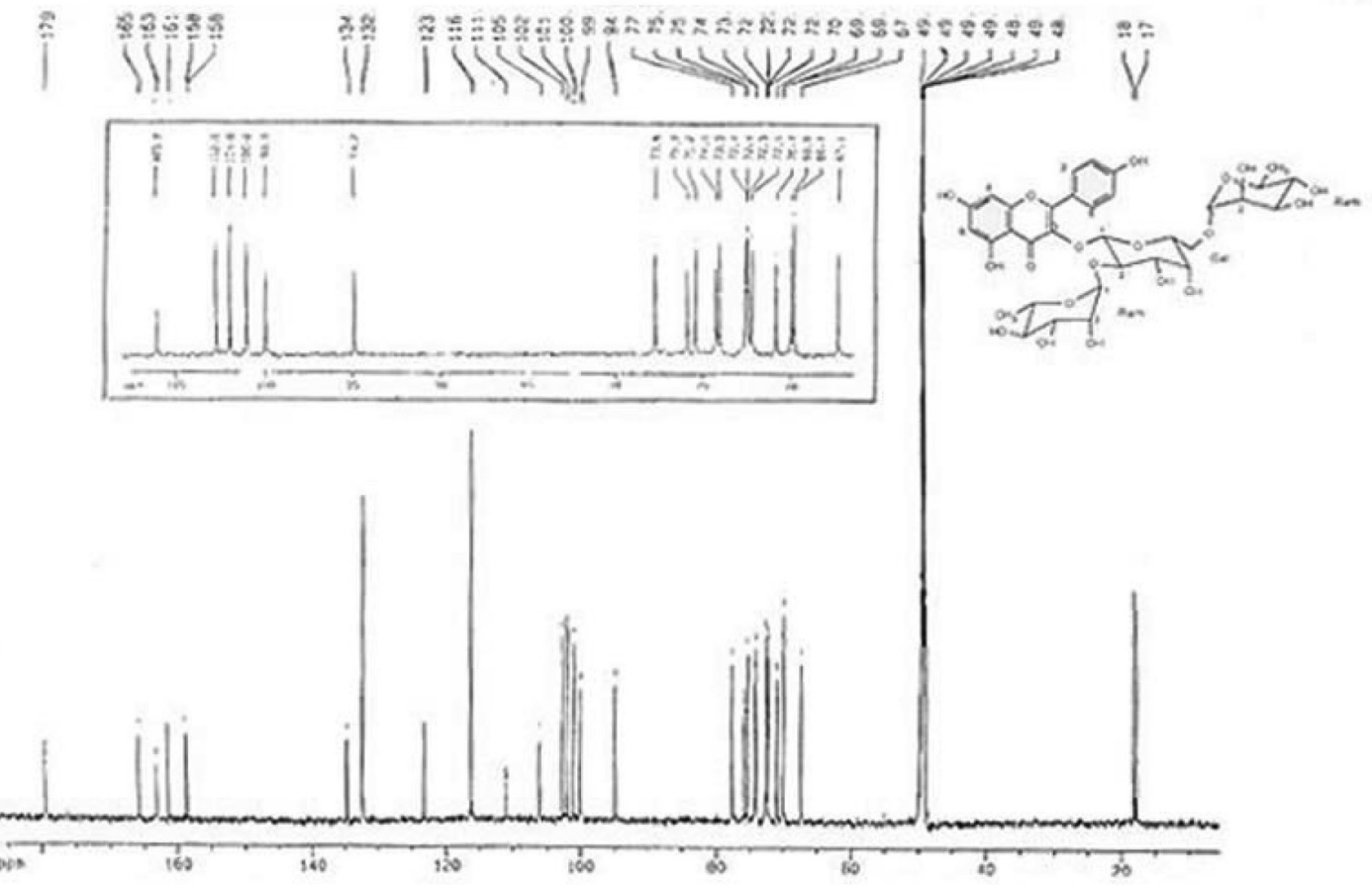

Figure S6. ${ }^{13} \mathrm{C}$ NMR spectrum of compound $\mathbf{1}$.

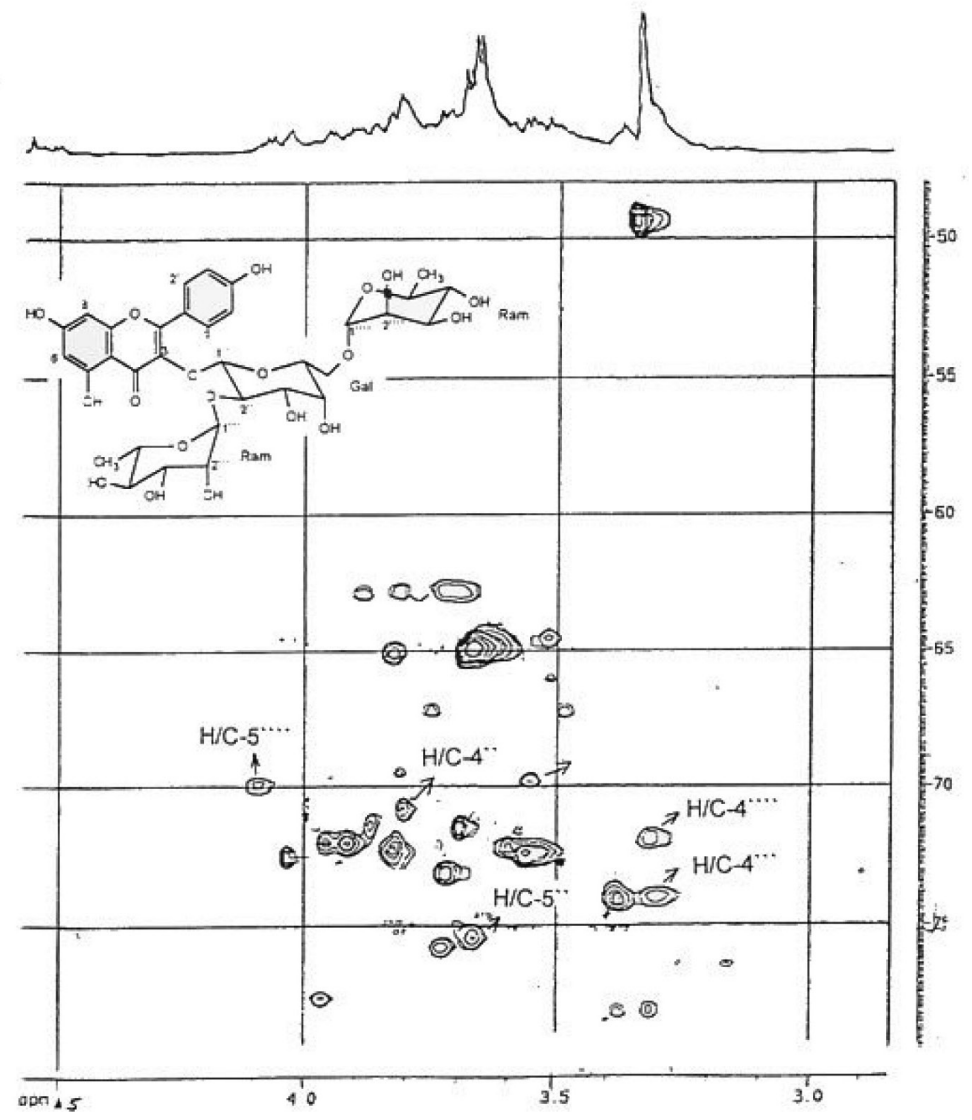

Figure S7. HSQC spectrum of compound 1. 


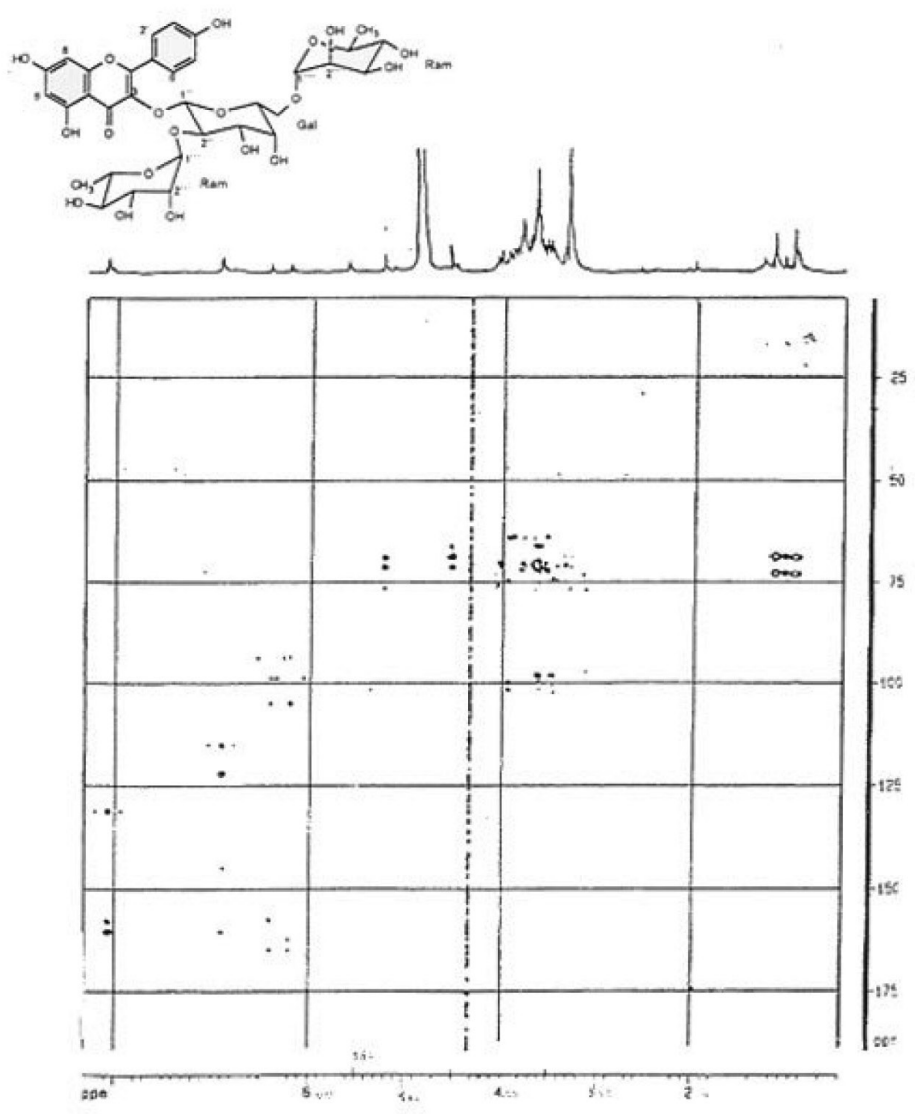

Figure S8. HMBC spectrum of compound $\mathbf{1}$.

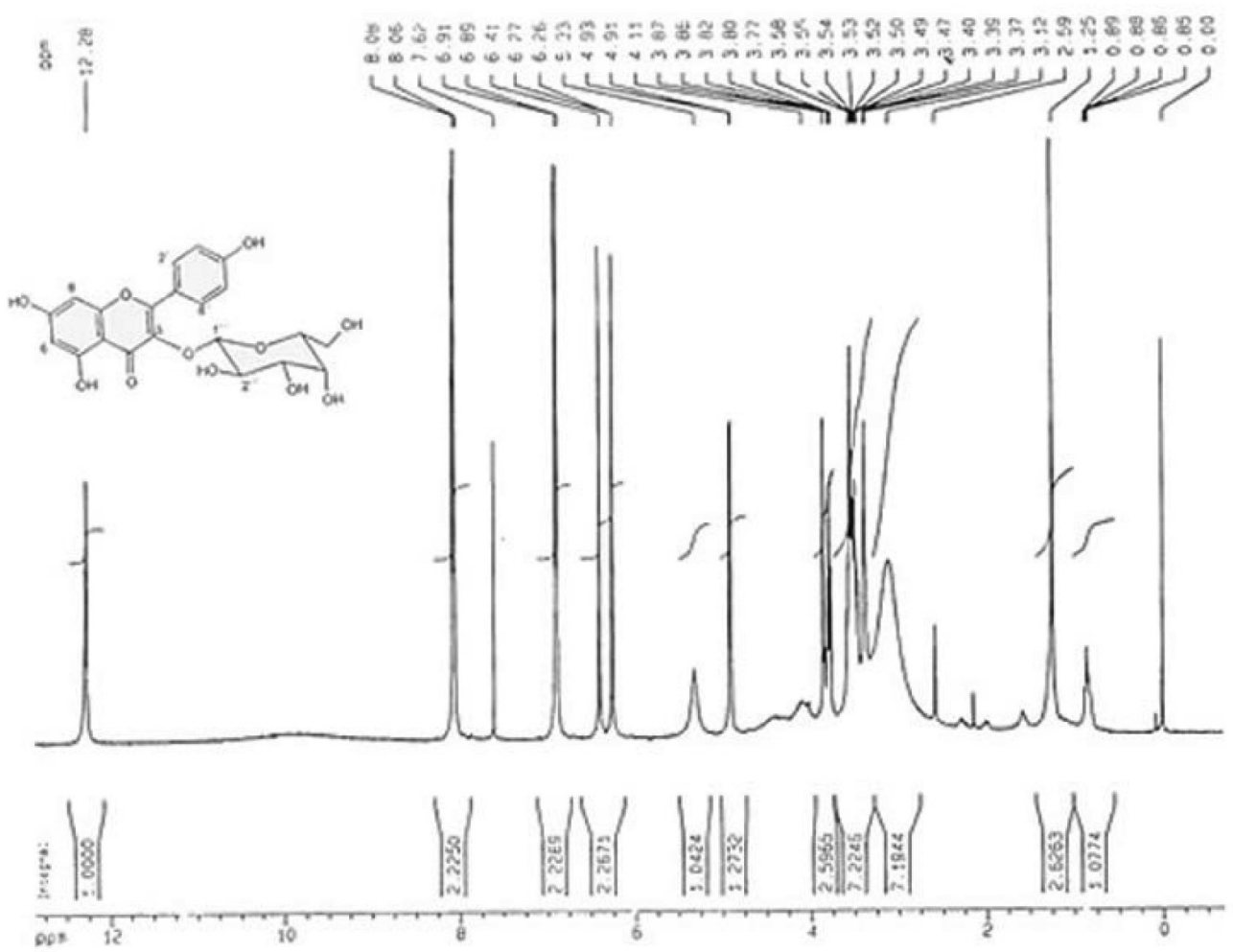

Figure S9. ${ }^{1} \mathrm{H}$ NMR spectrum of compound 2. 


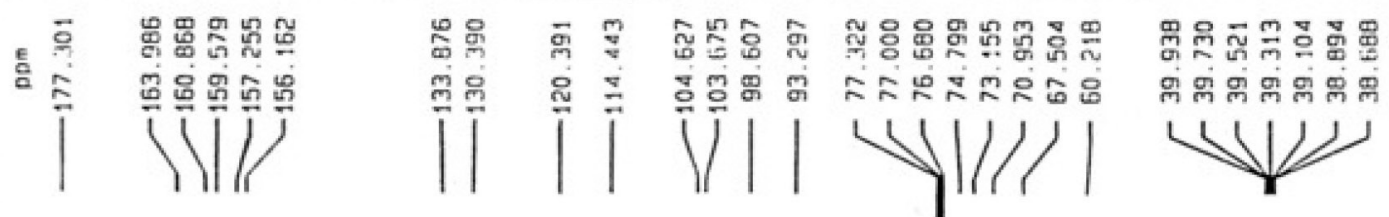<smiles></smiles>
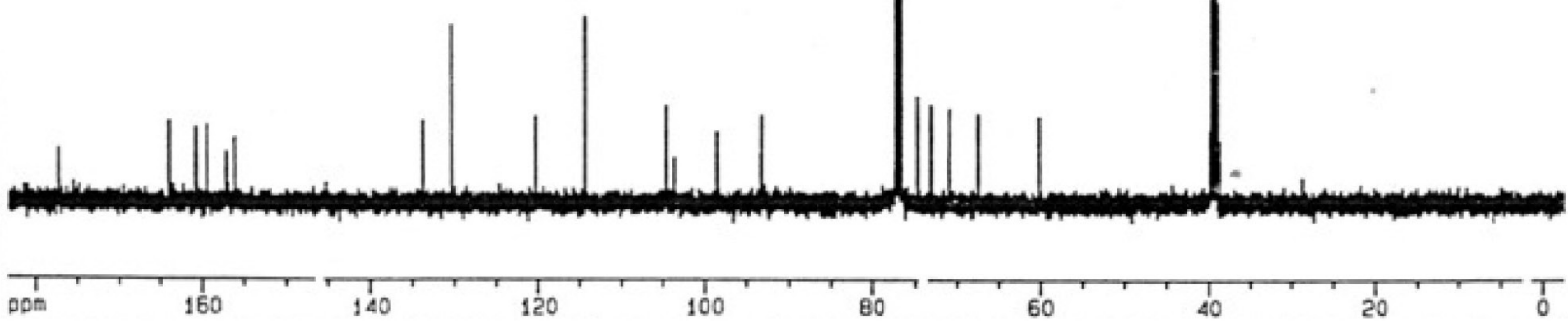

Figure S10. ${ }^{13} \mathrm{C}$ NMR spectrum of compound 2.

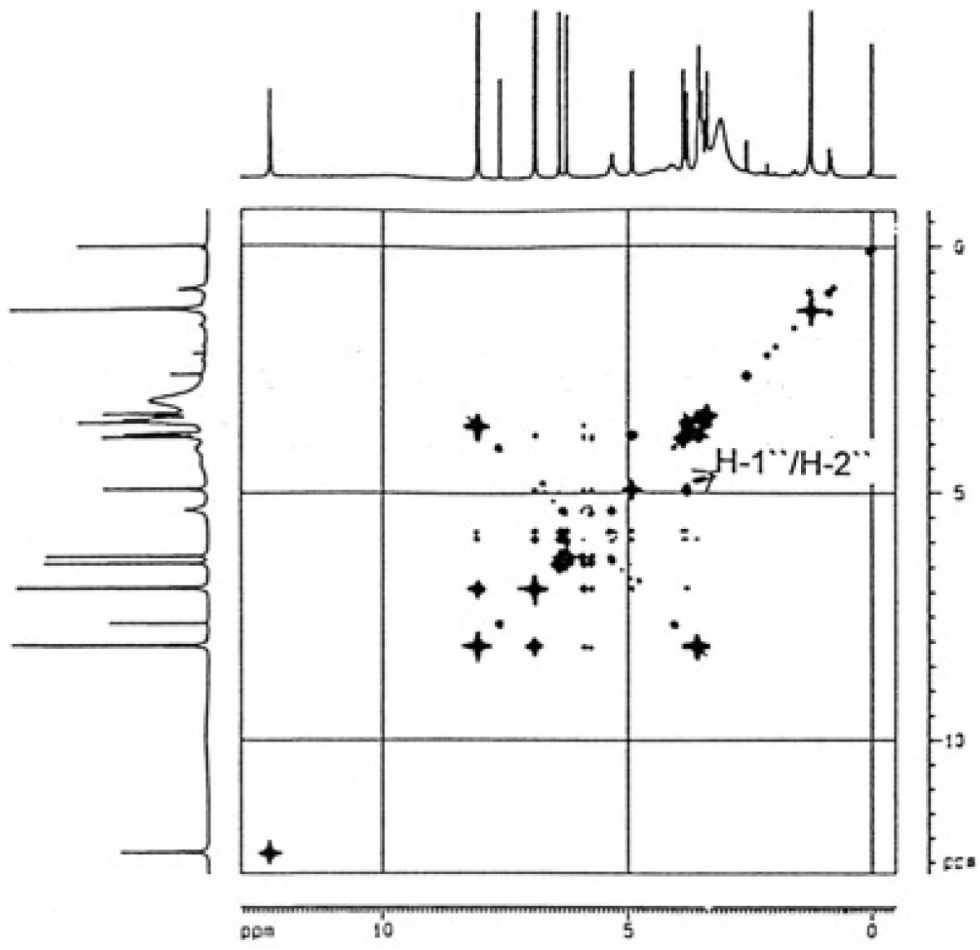<smiles></smiles>

Figure S11. COSY experiment of compound 2. 


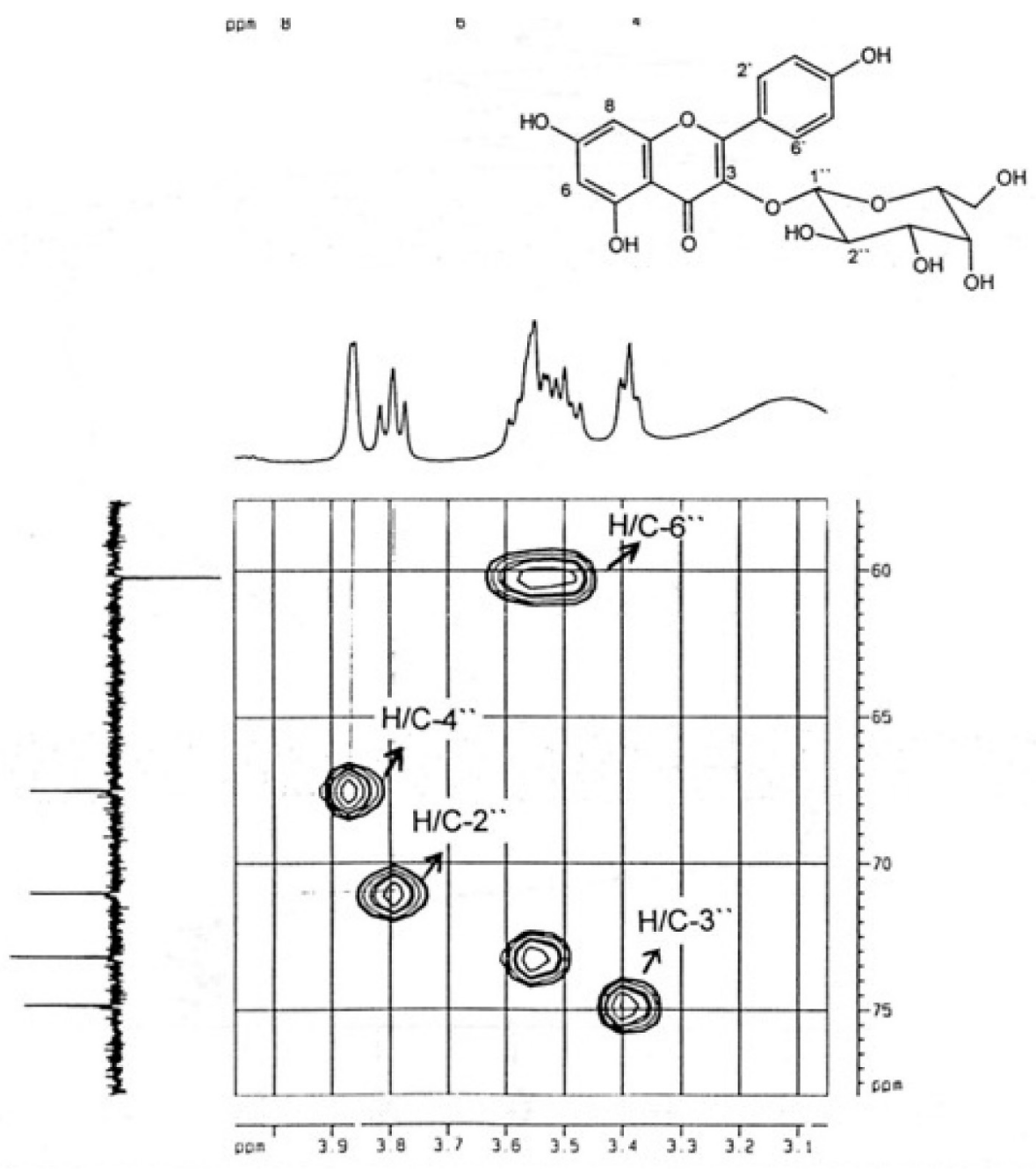

Figure S12. HMQC spectrum of compound 2. 


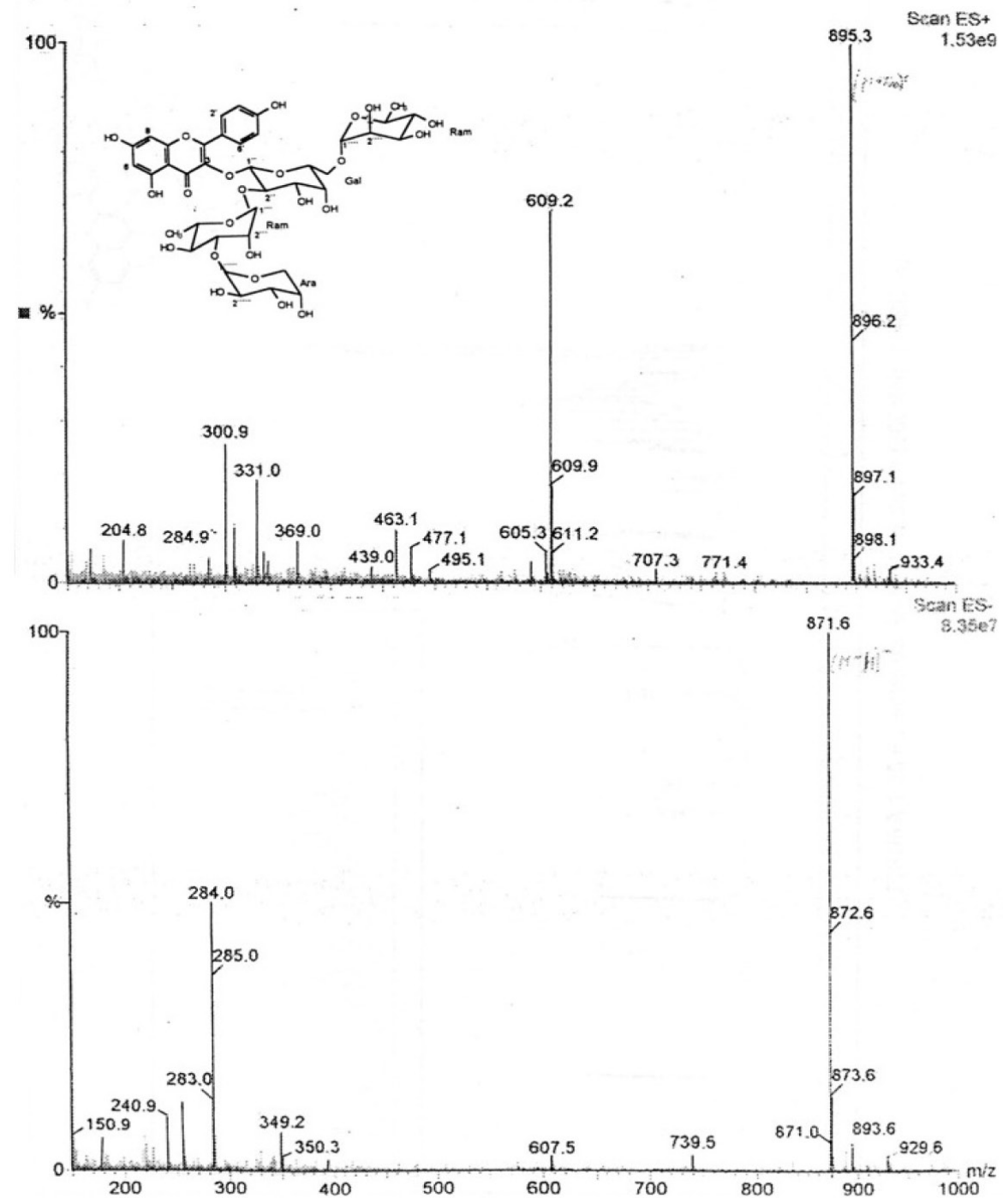

Figure S13. Mass spectrum of compound 3. 


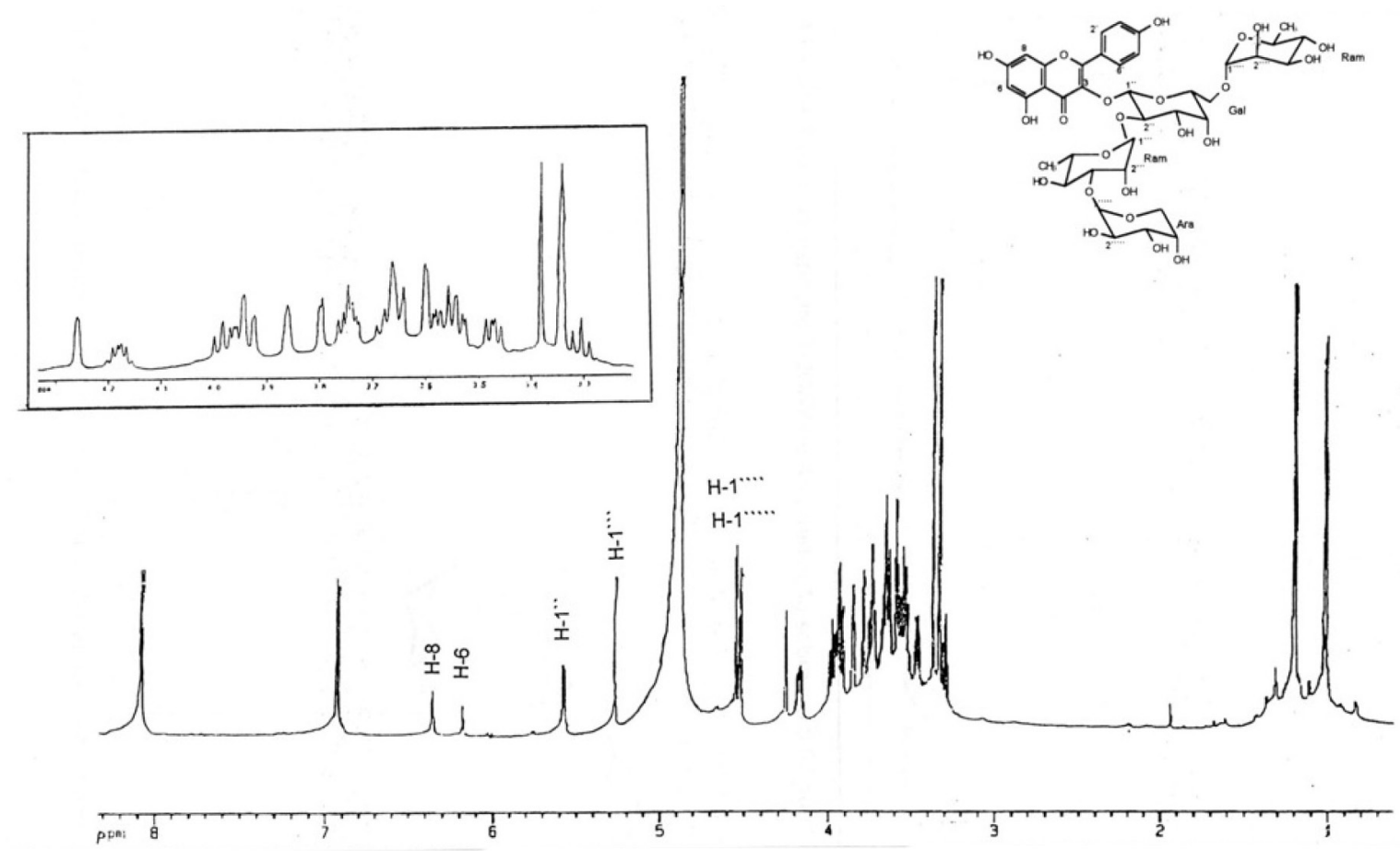

Figure S14. ${ }^{1} \mathrm{H}$ NMR spectrum of compound 3.

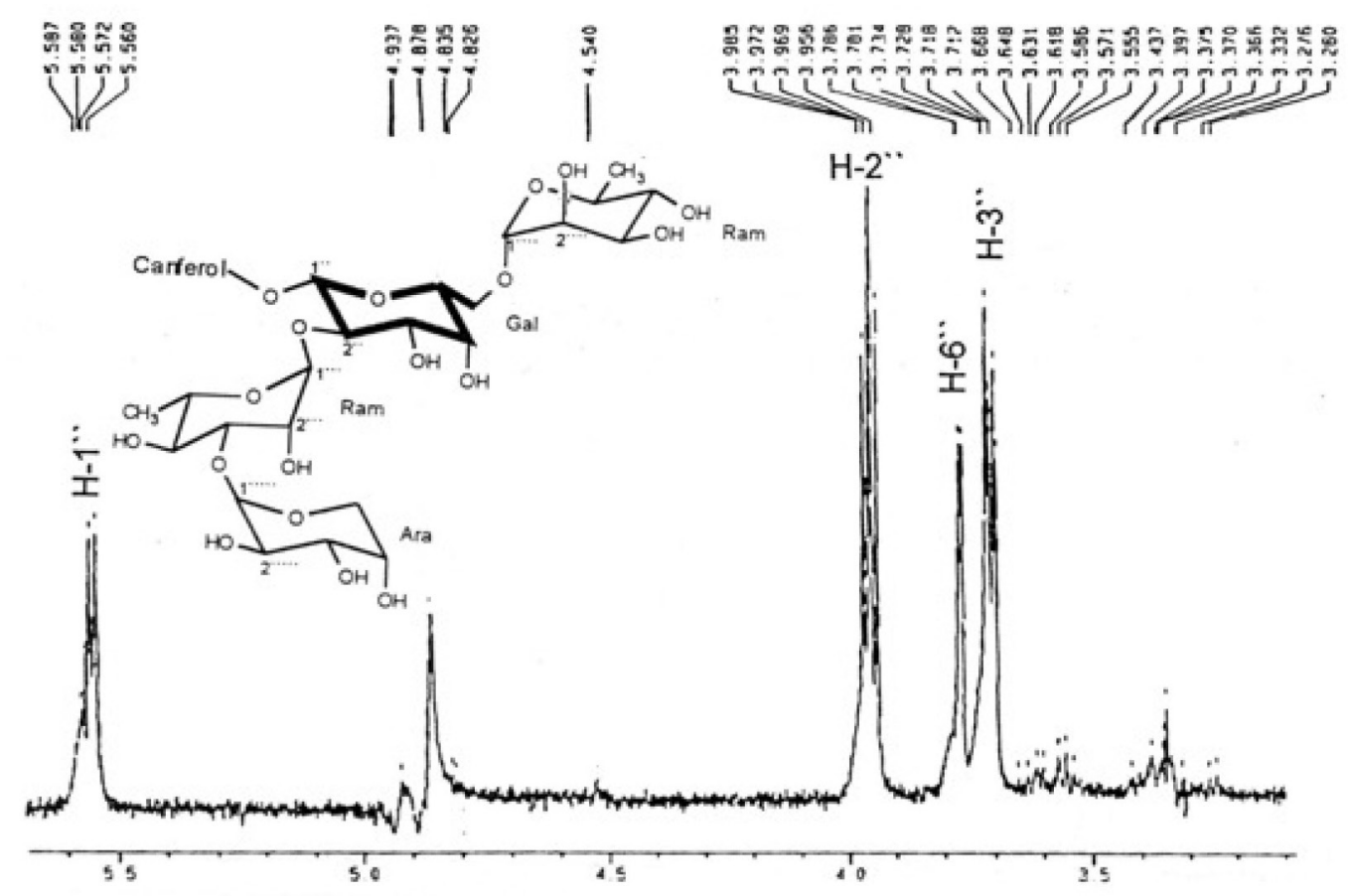

Figure S15. ${ }^{1} \mathrm{D}$ TOCSY experiment of compound $\mathbf{3}$ with selective excitation at $\delta 5.57 \mathrm{ppm}$. 


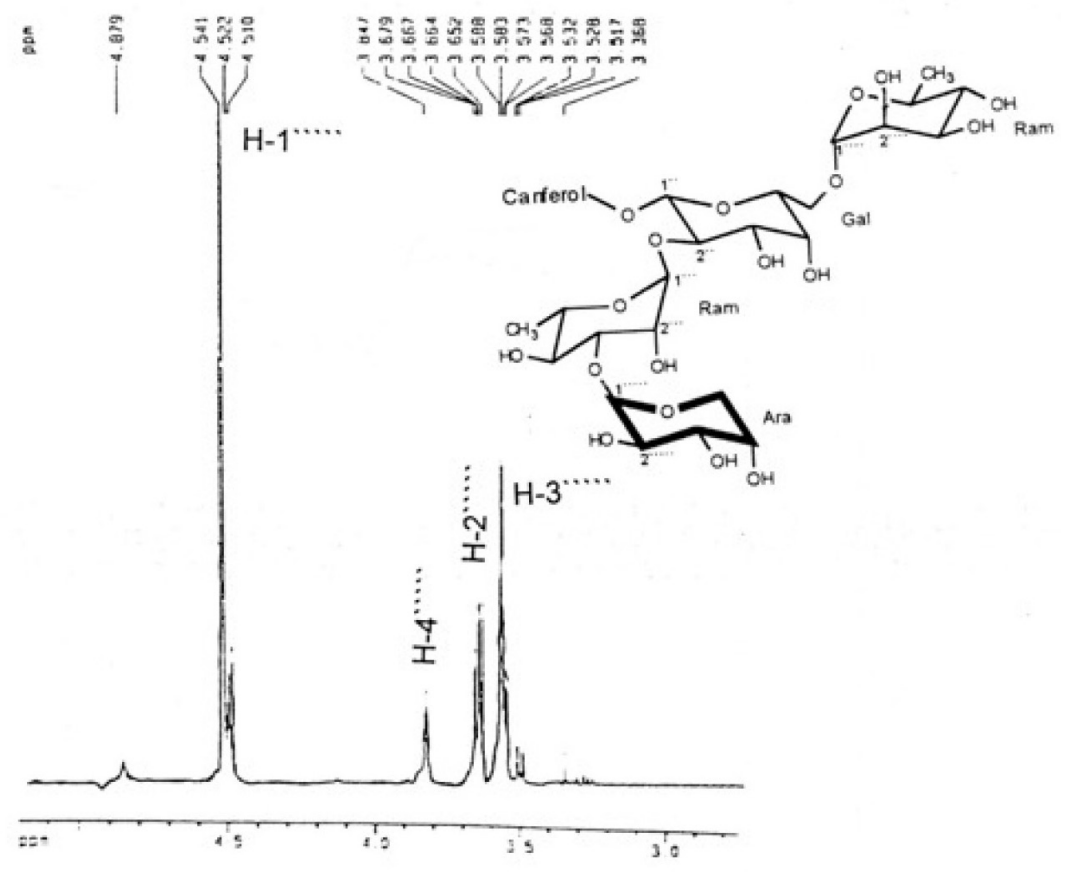

Figure S16. ${ }^{2}$ D TOCSY experiment of compound $\mathbf{3}$ with selective excitation at $\delta 4.52 \mathrm{ppm}$.
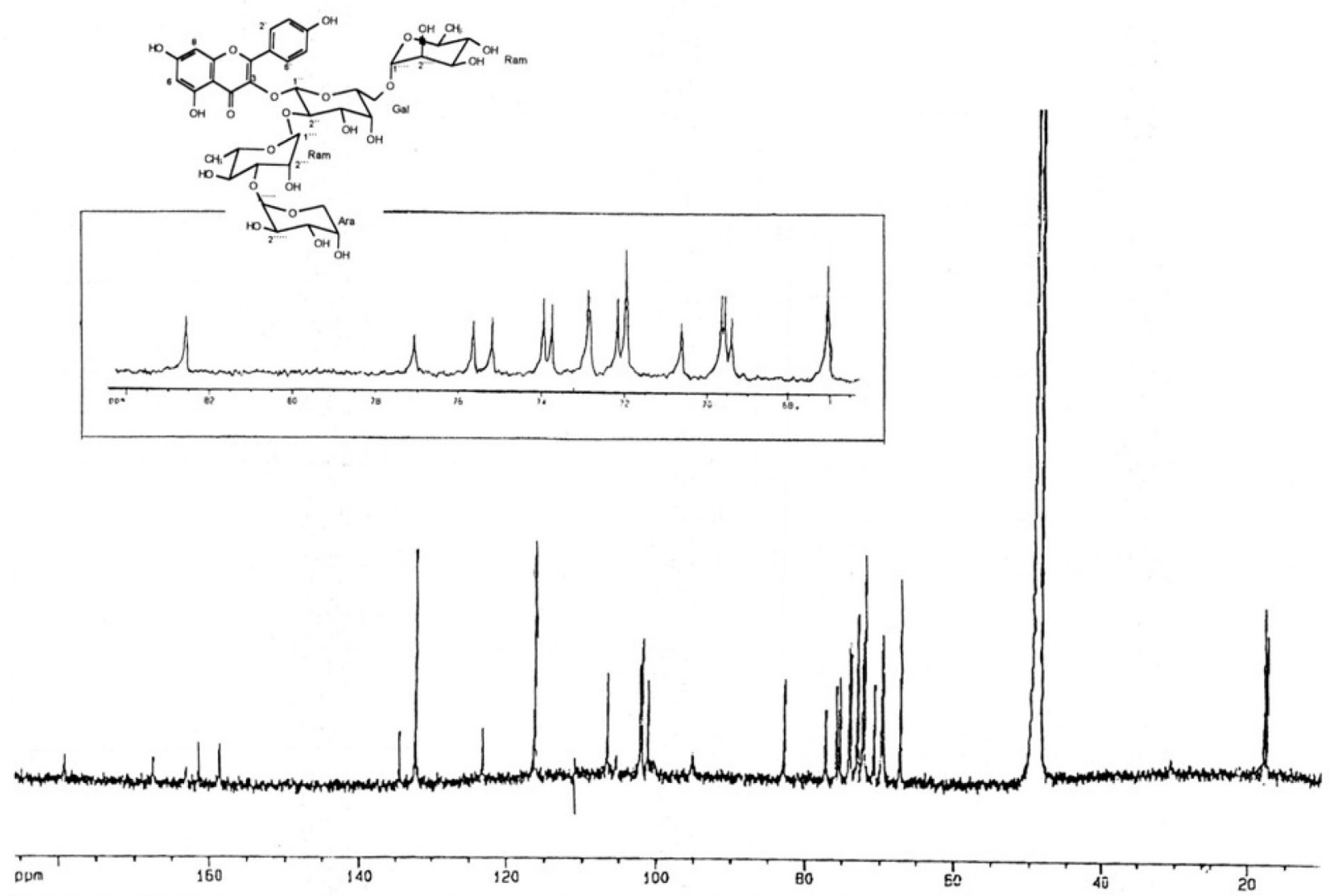

Figure S17. ${ }^{13} \mathrm{C}$ NMR spectrum of compound 3 . 


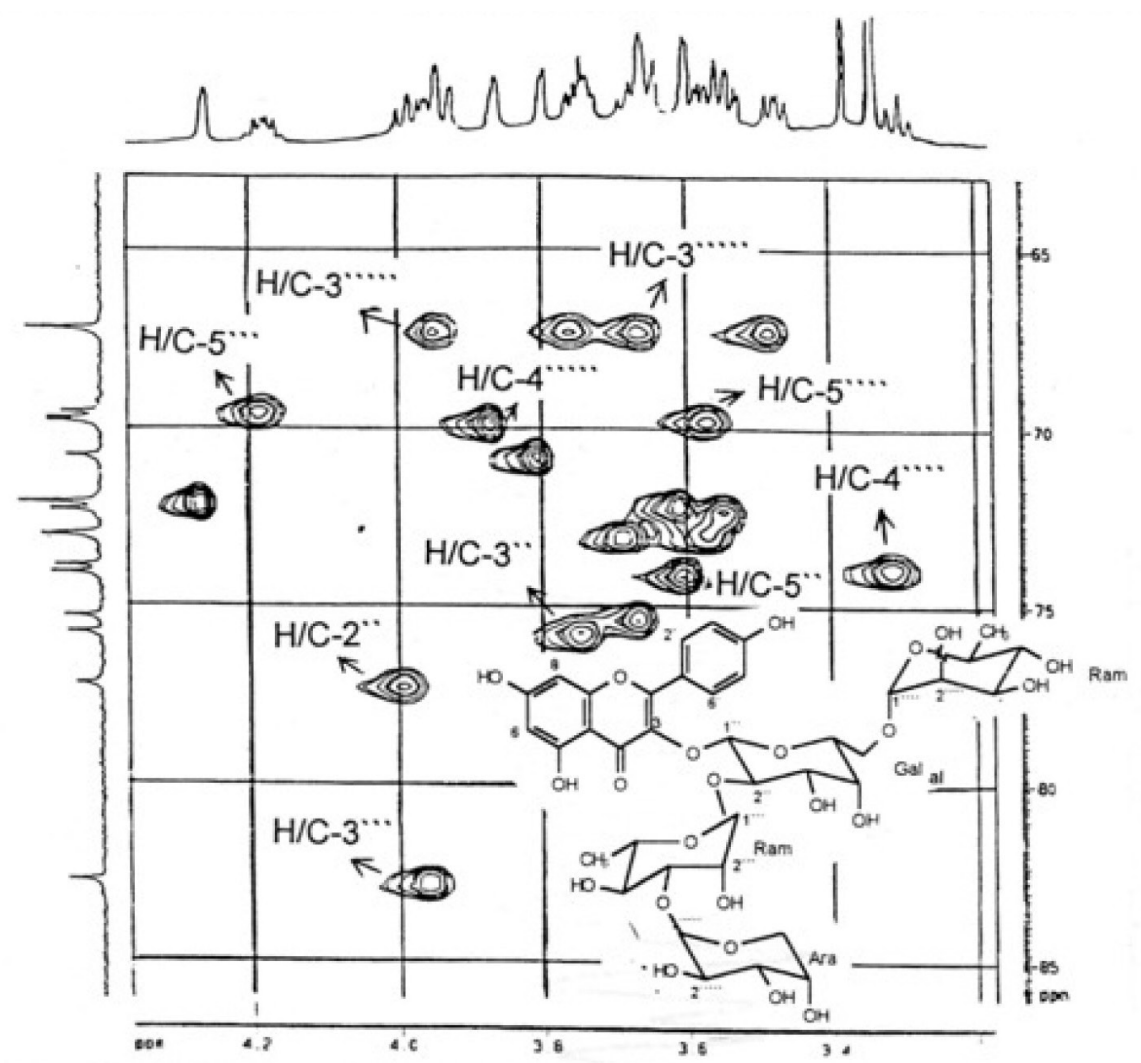

Figure S18. HSQC spectrum of compound 3.

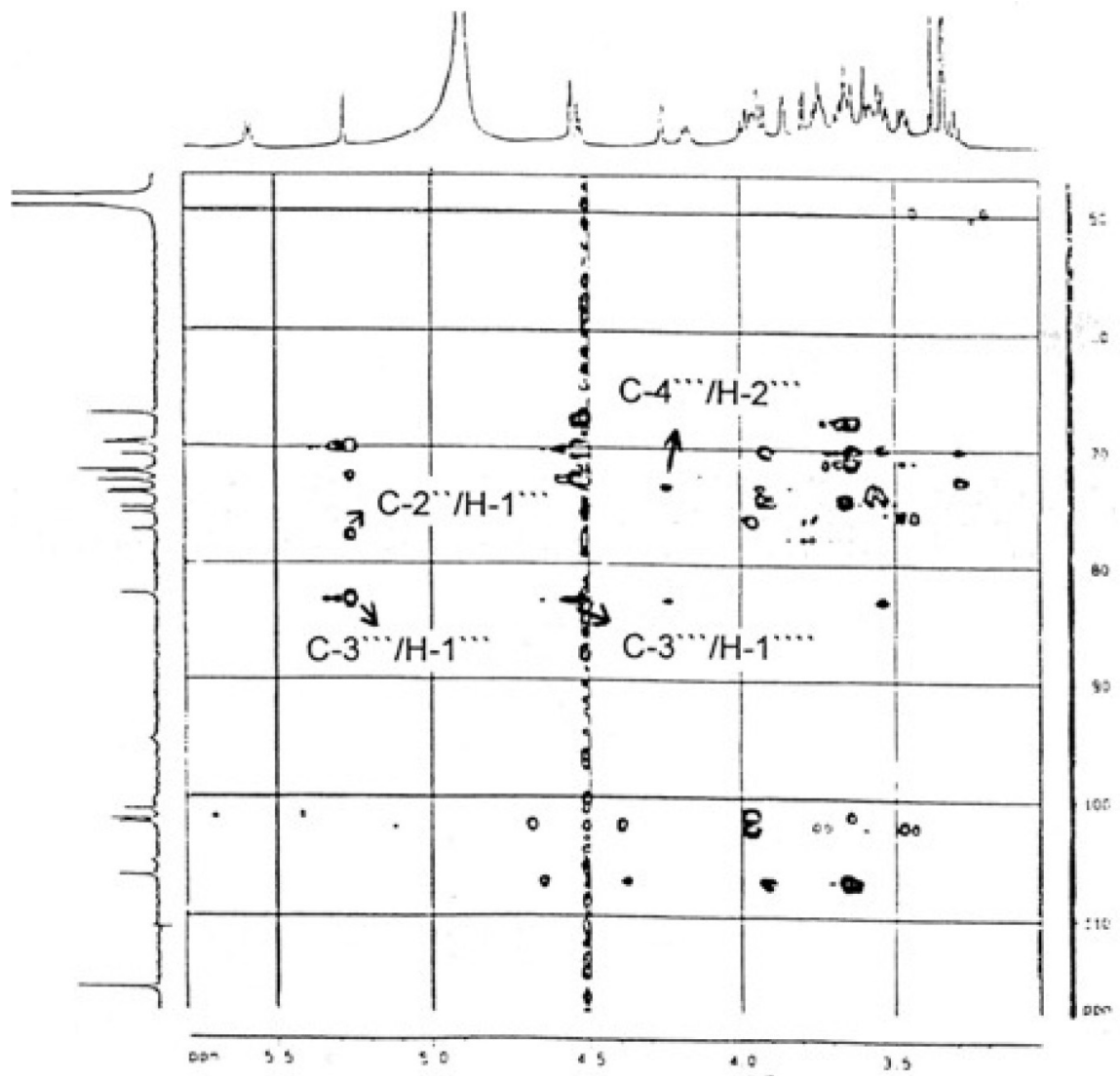

Figure S19. HMBC spectrum of compound 3 . 

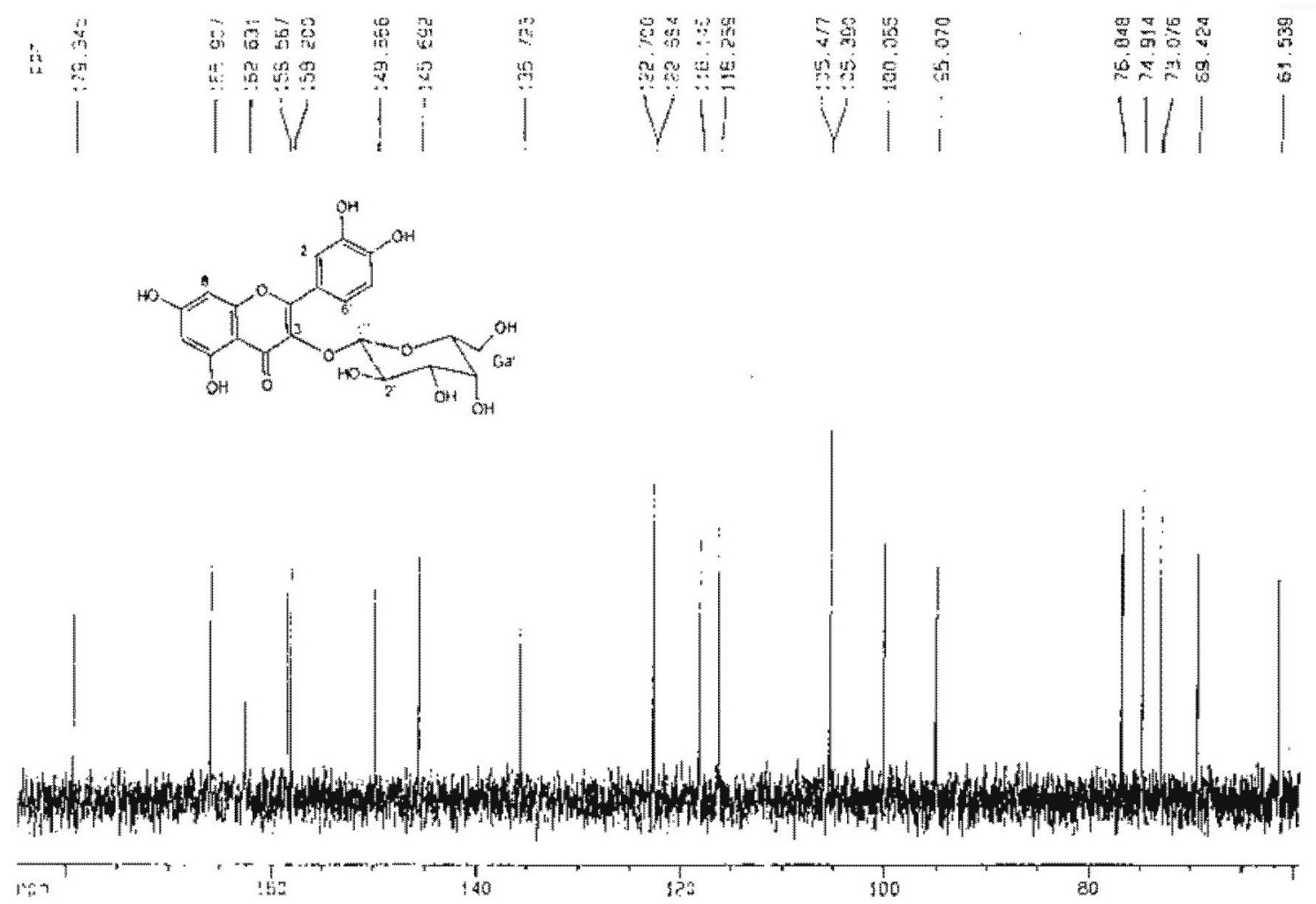

Figure S20. ${ }^{1} \mathrm{H}$ NMR spectrum of compound 4 .
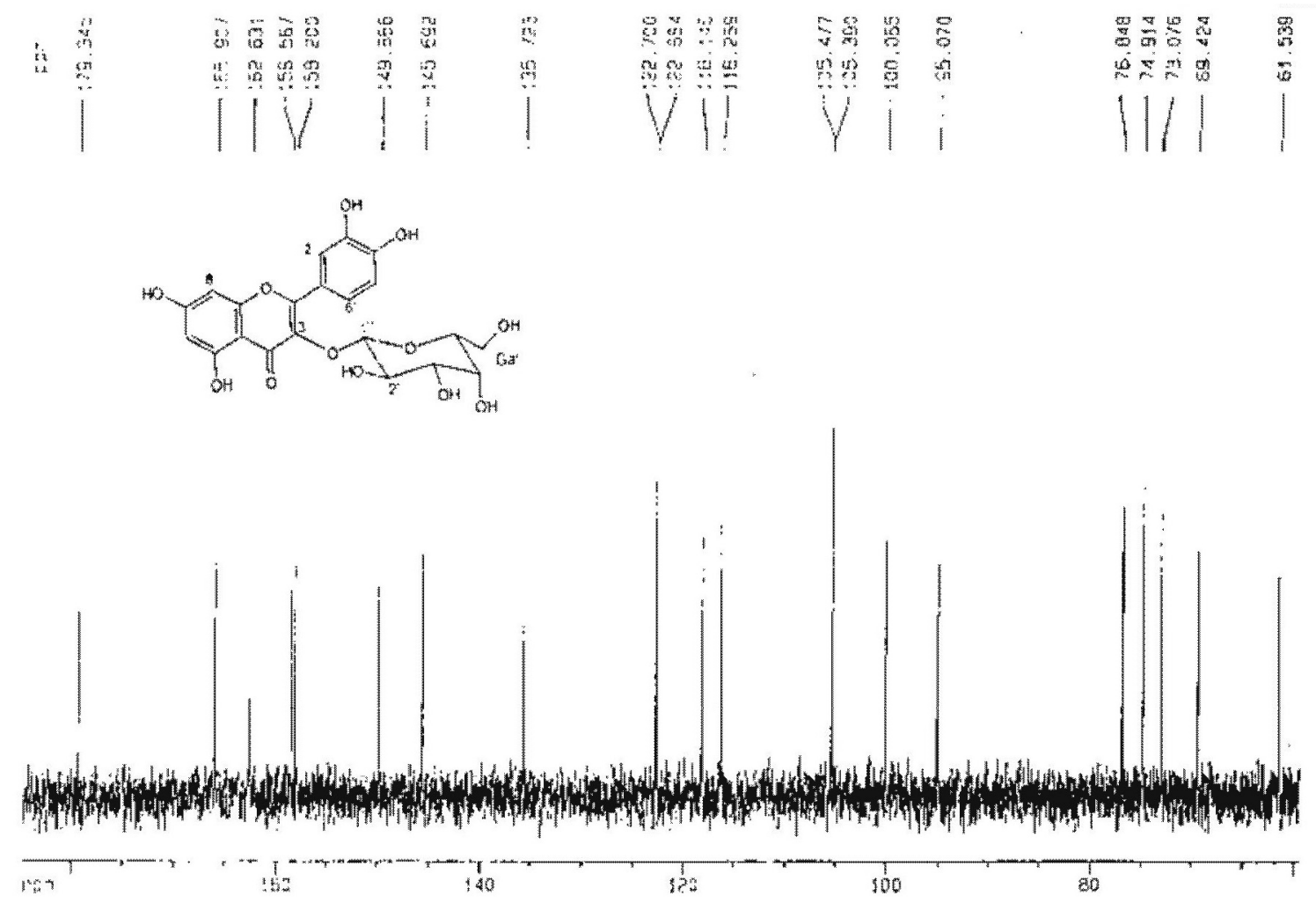

Figure S21. ${ }^{13} \mathrm{C}$ NMR spectrum of compound 4 . 


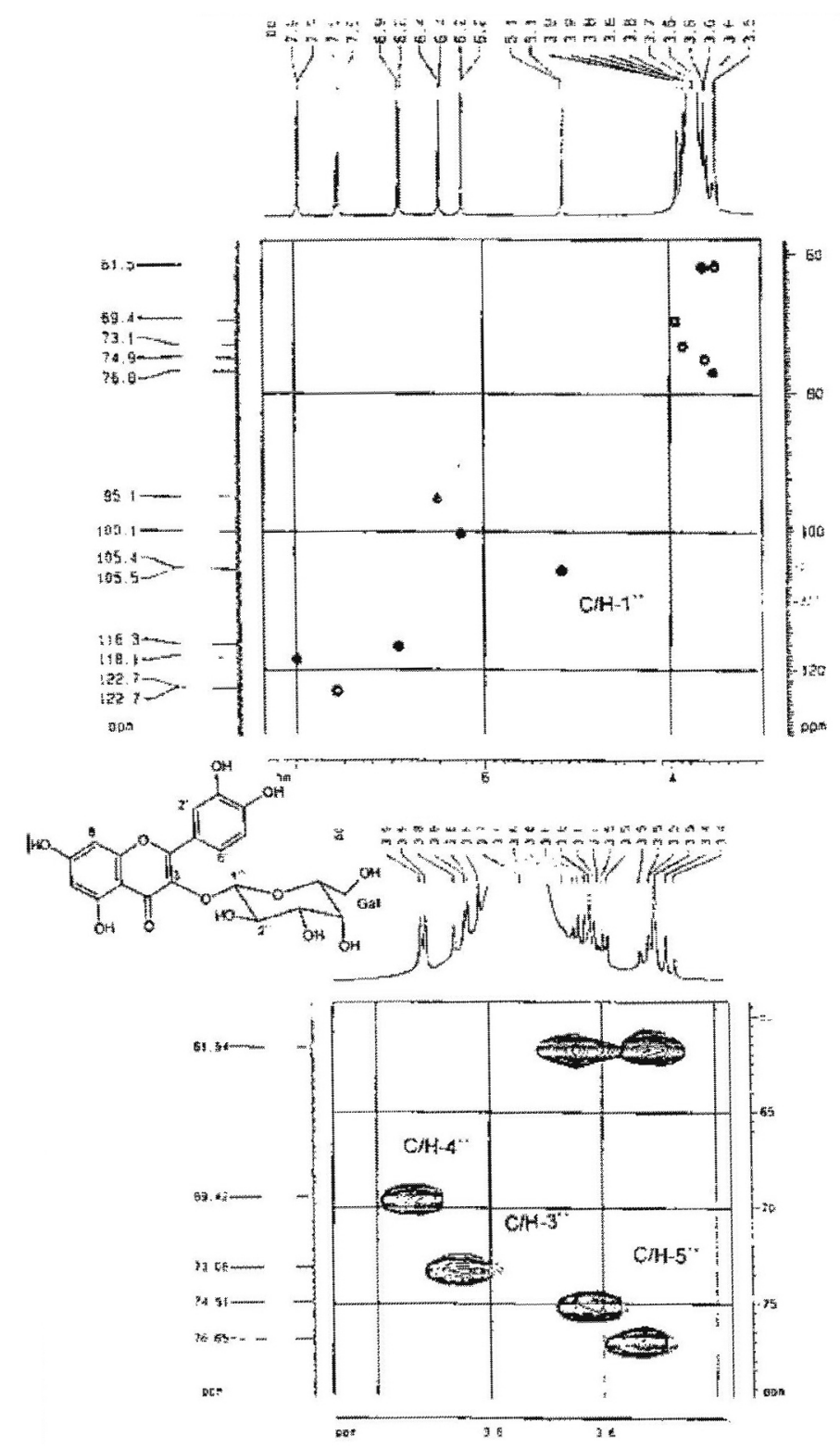

Figure S22. HMQC spectrum of compound 4. 


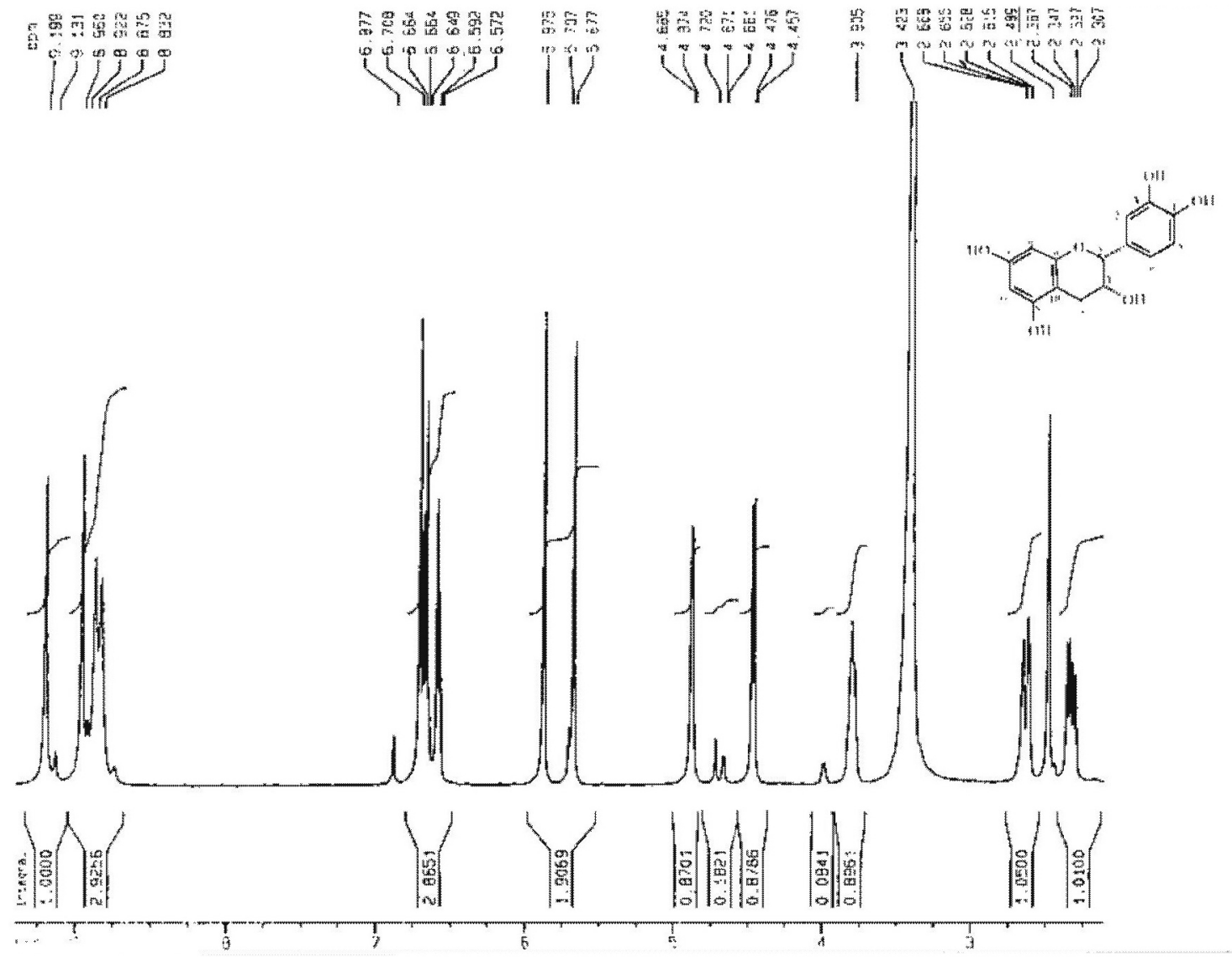

Figure S23. ${ }^{1} \mathrm{H}$ NMR spectrum of compound $\mathbf{5}$.

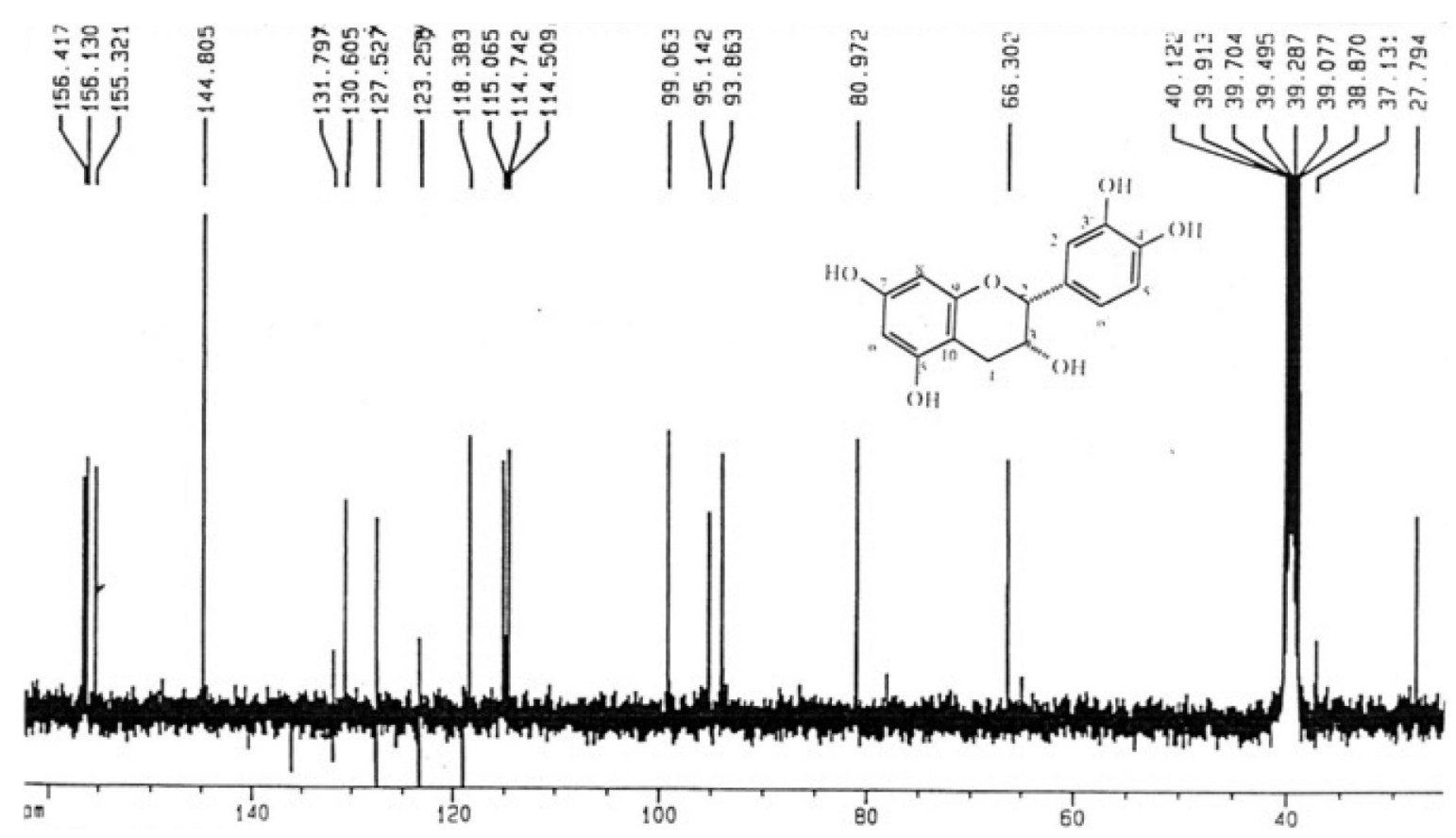

Figure S24. ${ }^{13} \mathrm{C}$ NMR spectrum of compound 5 . 


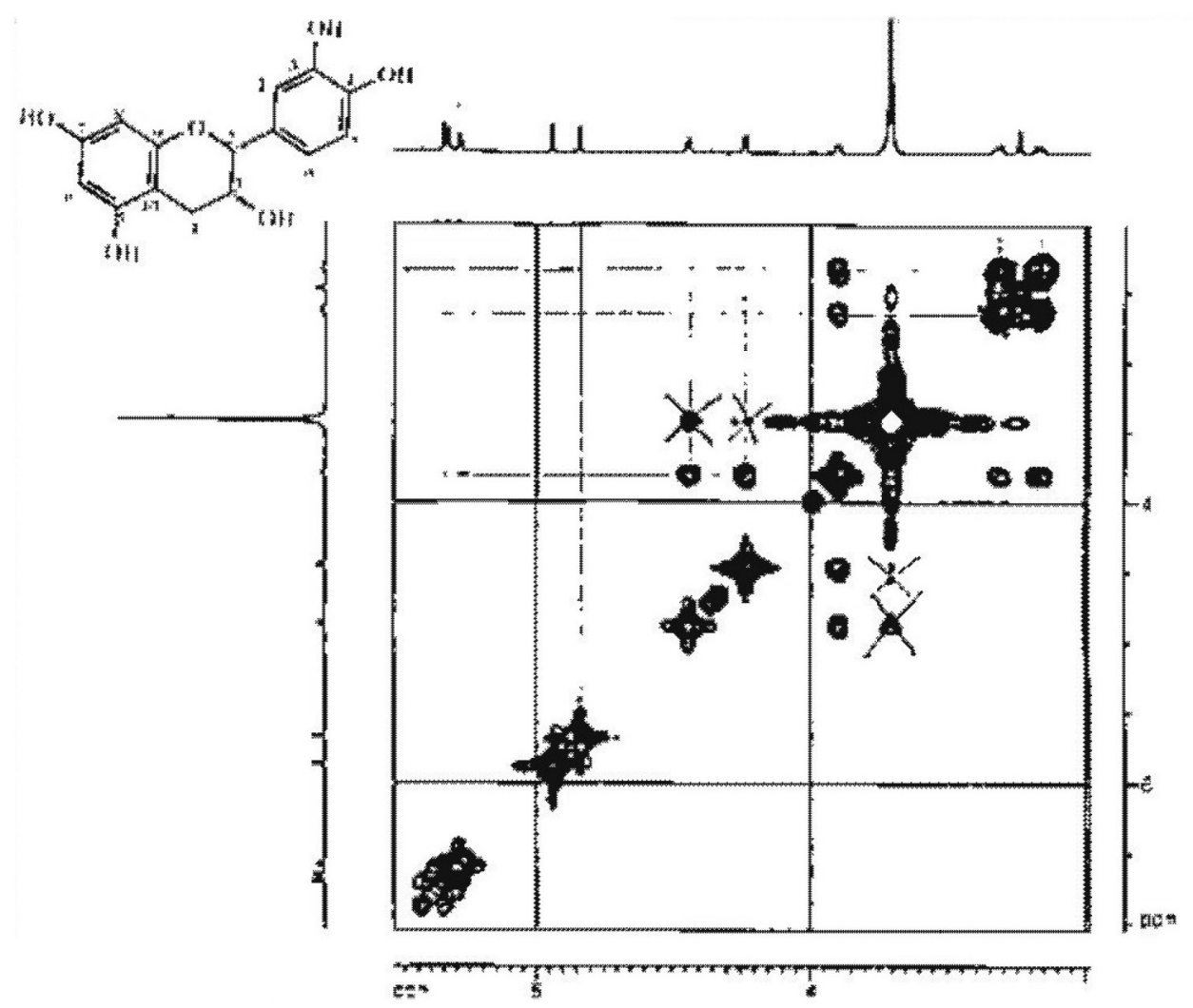

Figure S25. COSY experiment of compound 5.

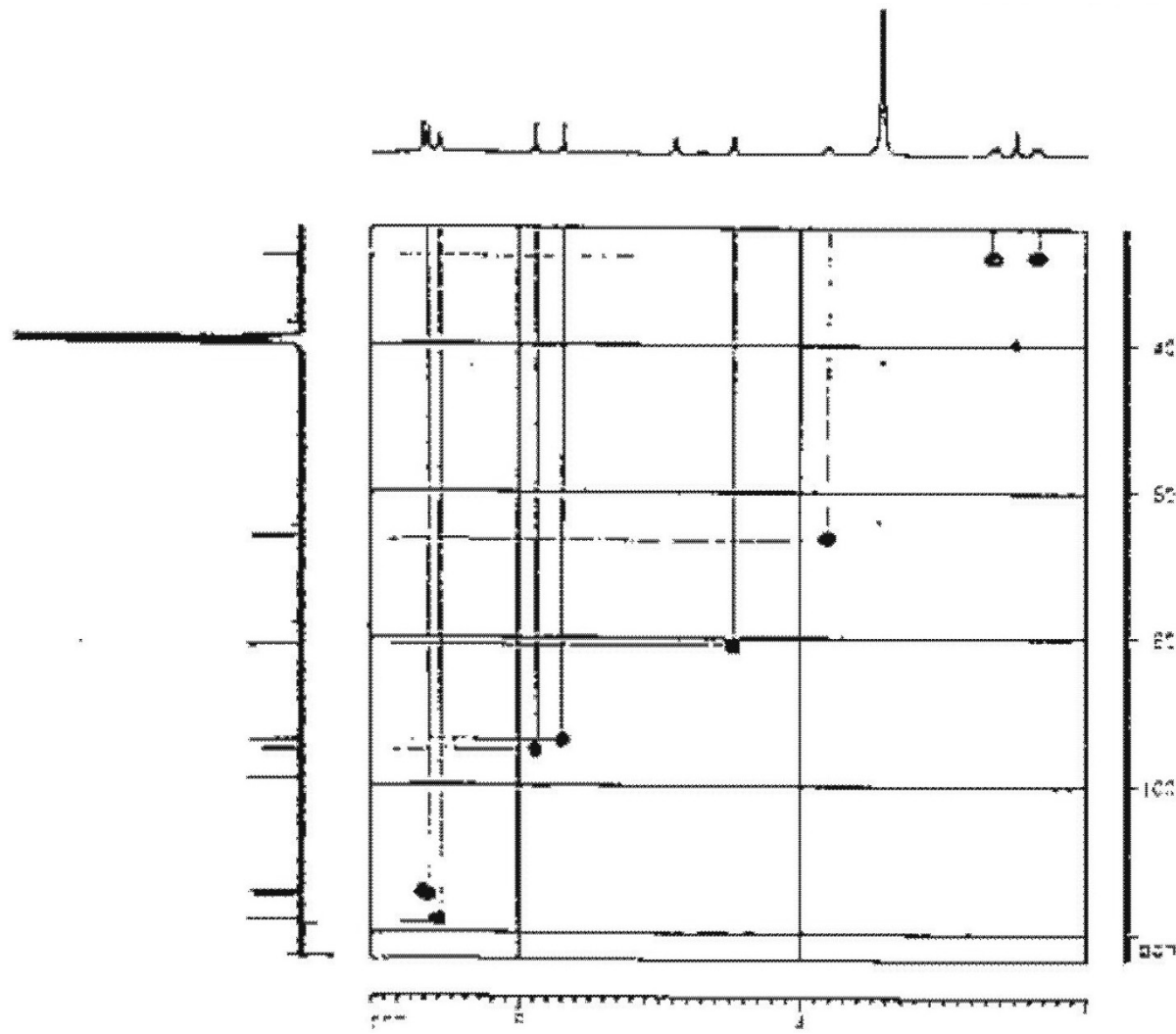

Figure S26. HMQC spectrum of compound 4. 


$$
\begin{aligned}
& \text { 泗怘吕 } \\
& \text { 도요에 }
\end{aligned}
$$

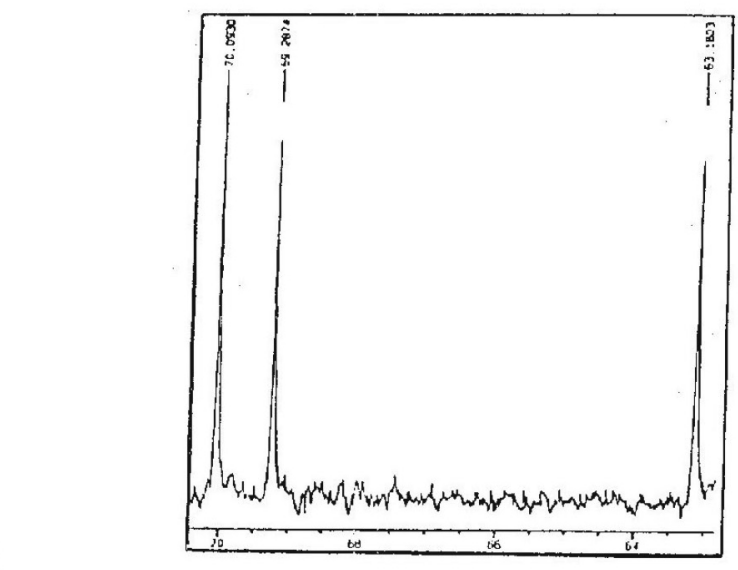

(V)

$$
\mid \begin{array}{c|c|c|c|}
\mathrm{H}-1 & \mathrm{OH} \\
\mathrm{H}-2 & \mathrm{OH} \\
\mathrm{HO}-3 & \mathrm{H} \\
\mathrm{HO}-4 & \mathrm{H} \\
\mathrm{H}-5 & \mathrm{OH} \\
\mathrm{II}-6 & \mathrm{H} \\
\hline & \mathrm{OH}
\end{array}
$$
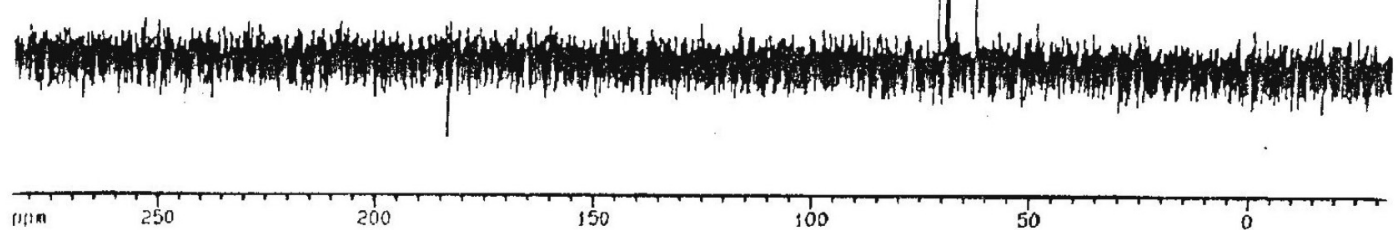

200

150

100

50

T.

S27. ${ }^{13} \mathrm{C}$ NMR spectrum of compound 6 . 